\title{
PUBLIC OPINION: BIBLIOMETRIC ANALYSIS FOR THE SYSTEMATIZATION OF TRENDS
}

\author{
A. E. F. A. SILVA*, J. W. PRADO, V. C. ALCÂNTARA, D. F. TONELLI, J. R. PEREIRA \\ Universidade Federal de Lavras \\ anaeliza.alvim@gmail.com*
}

Received 08/08/2018 - Accepted 26/09/2018

DOI: $10.15628 /$ holos.2018.6905

\section{ABSTRACT}

This paper sought to identify trends in the research of "public opinion", allowing for an analysis of the field in a systematized manner. We carried out a bibliometric study of 2,536 articles selected from the Web of Science. We aimed to characterize the research front and intellectual base of the field. In relation to the research front, we noted an increase in publications between 1945 and 2016; we identified Robert Shapiro and Lawrence Jacobs as the most productive authors; among the most referenced articles were those by Gamson and Modigliani (1989) and Page and Shapiro (1983). We also identified that the majority of articles are: by North American authors; were published in the journals Public Opinion Quarterly and Sotsiologicheskie Issledovaniya;
\end{abstract}

are indexed in the categories of Government \& Law and Political Science and represented by the keywords public opinion, attitudes, support, policy, the United States and politics. With regard to the intellectual base in the journal co-citation network, the Public Opinion Quarterly, American Political Science Review and American Journal of Political Science stood out. In the author co-citation network the most prominent authors were Page and Zaller. In the analysis of the references co-citation, the most frequent texts in the network were by Zaller (1992) and Page and Shapiro (1992). We concluded that scientific output on public opinion is on the increase, with a dynamic expansion of the research front and intellectual base.

\section{OPINIÃO PÚBLICA: UMA ANÁLISE BIBLIOMÉTRICA PARA SISTEMATIZAÇÃO DE TENDÊNCIAS}

\section{RESUMO}

Este trabalho buscou identificar as tendências de pesquisa sobre "opinião pública", permitindo analisar o campo de forma sistematizada. Realizamos um estudo bibliométrico com 2.536 artigos selecionados na Web of Science. Buscamos caracterizar a frente de pesquisa e a base intelectual do campo. Em relação à frente de pesquisa, observamos um aumento nas publicações entre 1945 e 2016; identificamos Robert Shapiro e Lawrence Jacobs como os autores mais produtivos; entre os artigos mais referenciados foram aqueles de Gamson e Modigliani (1989) e Page e Shapiro (1983). Identificamos também que a maioria dos artigos: é de autores norte-americanos; foi publicada nos periódicos Public Opinion Quarterly e Sotsiologicheskie
Issledovaniya; está indexada nas categorias Government \& Law e Political Science e representada pelas palavraschave public opinion, attitudes, support, policy, unitedstates e politics. Quanto à base intelectual na journal cocitation network, foram destaques os periódicos Public Opinion Quarterly, American Political Science Review e American Journal of Political Science. Já a author cocitation network possui como mais proeminentes os autores Page e Zaller. $\mathrm{Na}$ análise das references cocitation, os textos mais frequentes na rede foram de Zaller (1992) e Page and Shapiro (1992). Concluímos que a produção científica sobre opinião pública está em ascensão, com ampliação dinâmica da frente de pesquisa e da base intelectual.

PALAVRAS-CHAVE: Opinião Pública; Literatura Científica; Bibliometrics; CiteSpace. 


\section{INTRODUCTION}

The concept of public opinion has provoked controversy (Bourdieu, 1980; Mateus, 2008). There are even those who claim that public opinion does not exist (Bourdieu, 1980). The controversy is due to the fact that "[...] the centrality of public opinion in social and political thinking renders it a fundamental symbolic value for societies. It effectively served as the basis for revolutions, democratic movements or to support totalitarian regimes" (Mateus, 2008, p. 59). It is still common to encounter the assertion that "[...] there can be no democracy without the democratic formation of public opinion" (Guimarães \& Amorim, 2013, p. 53). From this perspective, public opinion is fundamental in shaping political will, as Jürgen Habermas, and before him, Jean-Jacques Rousseau both argued - despite the limitations of both propositions (Guimarães \& Amorim, 2013).

The literature on public opinion in the 20th century makes expressive reference to the works: Public Opinion, by Walter Lippmann, 1922, and Kritik der Öffentlichen Meinung (translated as On Public Opinion), by Ferdinand Tönnies, also in 1922. Non-systematic evidence shows that there has been discussion on the theme by authors from different strands and epistemologies, as well as from different areas of knowledge and with various research themes. In the light of this, it becomes important to discover the trends in academic production involving the concepts of "public opinion".

We sought to answer this question through a bibliometric analysis, which aims to organize scientific output trends and comprehend how a certain area of knowledge has been developing (Prado et al., 2016). Investigations such as these also propose an analysis of the dynamics associated with the formation, maintenance and decline of some scientific communities (Hagstrom, 1965) or scientific fields (Bourdieu, 1994). As such, the goal of this paper was to systematize trends in the field of "public opinion" surveys. To this end, we used Web of Science as base for the gathering of bibliographical material.

Following this introduction, there are another four sections: (i) brief theoretical presentation of the debates on public opinion; (ii) presentation of methodological research procedures; (iii) results and discussion and, finally, (iv) conclusions.

\section{ORIGINS OF THE EXPRESSION “PUBLIC OPINION"}

It is worth noting that due to the bibliometric analysis character of the article, this segment of text aims to merely identify some elements of the field.

To begin our reflection of the studies that deal with public opinion, we need to remember that although modern historical definitions of the expression "public opinion" date back to the 18th century and start of the 19th century, they are still related to the two isolated terms that form the expression - "opinion" and "public" - which have older origins (Borges, 2014; Mateus, 2008). It is important to note that the terms are initially in antithetic domains, since the former alludes to the individual, subjective and unstable world, while the latter refers to something objective, universal and common to various subjects (Borges, 2014; Mateus, 2008). The referral 
to the terms separately in order to understand the concept is emphasized by Price $(2008$, p. 11$)$ : "The concept of public opinion emerged during the Enlightenment, but the separate concepts of the public and opinion have much older histories, each with a range of meanings that continue to inform their use to the present day".

The origin of each term is in the political-philosophical thinking of Classical Antiquity. For Plato, opinion (doxa) was something ephemeral, unstable, based on popular belief, becoming something of less value in his estimation. In opposition was episteme with immutable ideas (Borges, 2014). A similar concept held sway among the Romans. Another meaning related to the term 'opinion' was proposed by John Locke - that of moral judgment, which is associated with social control, since it is through it that individuals are judged, attributing them with credit and reputation, or not (Borges, 2014).

The term 'public', according to Borges (2014), had a Roman definition that distinguished it in relation to the private, with a separation between private and common matters (also as per Hannah Arendt and Jürgen Habermas). These definitions underwent changes over the course of history. In the Middle Ages, for example, public was associated with the apparatus that was in the domain of the public (Habermas, 2003).

Through the junction of these terms (to a certain extent, antagonistic), between the end of the 18th century and the beginning of the 19th century, we had the emergence of the expression public opinion, in contexts involving attempts to implant and legitimize democratic models (Habermas, 2003). According to Borges (2014), public opinion was initially conceived as the "court" that legitimizes and monitors the exercise of political power (Habermas, 2003; Borges, 2014), in expressing the voice of the "enlightened public" (Borges 2014, p. 92). It consolidates itself as an offshoot of the Illuminist philosophies and revolutions at the start of modern times, securing its place in a context of a liberal economy and society dominated by the bourgeois, as an abstract authority that mediates between government and those governed. This debate was central in the work The Structural Transformation of the Public Sphere de Habermas and also in The Human Condition de Arendt.

It was, therefore, a concept rooted in critical publicity and important in overthrowing the Old Regime and the emergence of a new authority to which the governing leaders were accountable - the public. The process of elevating the public to a social category was slow and it is considered to have begun in the era of feudalism, after which, in the course of history, it was subject to the influence of events such as the development of capitalism, the creation of cities, new means of communication, the emergence of the press and the Protestant Reformation movement. All this contributed to the onset of a reading public who gathered in cafes and halls in European countries to inform themselves and converse about art, politics, religion, science and business - that is, the public illuminist sphere of the 18th century (Habermas, 2003). In these spaces, the conversations emerged from critical judgment.

However, according to Mateus (2008), the bourgeois operationalization of the expression is merely one among other possibilities, given that in other times and contexts, similar terms were used to designate comparable objectives. Since the 17th century, in England, precursors of "public opinion" such as "the sense of the people", "the common voice", "the general cry of the people" and "the public spirit" were used (Borges, 2014; Price, 2008; Habermas, 2003). 


\section{RESEARCH METHODOLOGY}

Bibliometric studies are used, for example, to identify the trends and growth of knowledge in a certain area over time; evaluate the productivity of individual authors, organizations and countries; identify the journals that publish most on a given theme; identify reference authors for specific subjects, among many other possibilities (Prado et al., 2016). Therefore, this approach entails a broad perspective on trends and patterns through networks of co-citations (Chen, 2006; Prado et al., 2016, Costa et al., 2017).

With the aim of ensuring precision and transparency in the collection and analysis of information we chose to adopt the framework of biometric analysis produced by Prado et al. (2016). The instrument establishes stages to be followed by the researcher in planning the study, data mining, selection, organization and analysis of the material that will constitute the corpus of the research (Figure 1).

\begin{tabular}{|c|c|c|c|}
\hline Stages & Procedures & & Description \\
\hline \multirow{3}{*}{1} & \multirow{3}{*}{$\begin{array}{l}\text { Operationalization and } \\
\text { search procedures }\end{array}$} & 1.1 & Choice of scientific bases or journals \\
\hline & & 1.2 & Demarcation of the terms that represent the field \\
\hline & & 1.3 & Operationalization of the search and filtering of articles \\
\hline \multirow{6}{*}{2} & \multirow{6}{*}{$\begin{array}{c}\text { Procedures for selection and } \\
\text { organization }\end{array}$} & 2.1 & Download of references - EndNote software \\
\hline & & 2.2 & Download of references in electronic spreadsheet format \\
\hline & & 2.3 & Download of references \\
\hline & & 2.4 & Organization of references in EndNote \\
\hline & & 2.5 & Organization of analysis matrix in electronic spreadsheet \\
\hline & & 2.6 & Importing data to analysis software \\
\hline \multirow{8}{*}{3} & \multirow{8}{*}{$\begin{array}{c}\text { Research front } \\
\text { (articles from Web of } \\
\text { Science) }\end{array}$} & 3.1 & Analysis of the volume of publications and time trends \\
\hline & & 3.2 & Analysis of article authorship (authors who publish most) \\
\hline & & 3.3 & Analysis of most cited articles \\
\hline & & 3.4 & Analysis of authors' country \\
\hline & & 3.5 & Analysis of journals \\
\hline & & 3.6 & Analysis of categories \\
\hline & & 3.7 & Analysis of keywords \\
\hline & & 3.8 & Description, study of relations and trends \\
\hline \multirow{4}{*}{4} & \multirow{4}{*}{$\begin{array}{l}\text { Intellectual base for the field } \\
\text { (co-citation networks) }\end{array}$} & 4.1 & Analysis of journal co-citation network \\
\hline & & 4.2 & Analysis of author co-citation network \\
\hline & & 4.3 & Analysis of reference co-citation network \\
\hline & & 4.4 & Description, study of relations and trends \\
\hline
\end{tabular}

Figure 1 - Organization framework of bibliometric analysis. Source: Adapted from Prado et al. (2016). 
According to the framework of bibliometric analysis presented, the first procedure for the operationalization of research was the choice of Web of Science by Thomson Reuters (Principal Collection of the Web of Science), since it is among the most complete and reliable sources for organizing scientific production in accordance with rigid standards of selection, being used by different scholars as a reference (Pinto, Serra, \& Ferreira, 2014). In the search, we used the expression "public opinion" or "public opinions" in brackets in the "title" field, that is, the term had to be in the title of the article - whereby the article would follow the central theme in its content. We only considered documents in the form of scientific article and in all the years available in the database -1945 to 2016 . Moreover, no specific area was demarcated. At the end of the filtering, we found 2,536 articles.

Next, the other steps detailed in Figure 1 were followed. It is worth highlighting that by using specific software, bibliometric studies allow the researcher to deal with a large volume of information, which would be difficult implementing other analysis procedures (Pinto et al., 2014). To organize the references, we used EndNote (Free EndNote Trial). Nevertheless, in this article, we mainly used CiteSpace software for network presentations (Chen, 2006). In the analysis, we adopted the procedures described by Chen $(2004,2006)$ regarding the use of CiteSpace to view intellectual turning points (Chen, 2004) and understand emerging trends and transient patterns (Chen, 2004) in a general manner.

Important characteristics of CiteSpace use refer to the concepts of research front and intellectual base. Research front is the "emerging thematic trends and surges of new topics" (Chen, 2006, p. 362) and the intellectual base is represented in CiteSpace by the co-citation networks. Citespace also allows for the presentation of clusters as the figure illustrates. Chen (2006) demonstrates that through citations and co-citations we can discover the research trends on public opinion, the research front and the intellectual base of the field. In this way, the researcher may view the existing relations in his/her research field.

In addition, to extend the analysis we used the software for citation analysis VOSviewer 1.6.7 (Van Eck \& Waltman, 2010) and CitNetExplorer 1.0.0 (Van Eck \& Waltman, 2014). Through them, it was constructed networks of co-citation (bibliometric maps) to better visualize the research field on public opinion. With its specificities, CitNetExplorer is a tool for analyzing and visualizing citation networks of scientific publications.

[...] CitNetExplorer offers sophisticated functionality for drilling down into a citation network, for instance allowing users to start at the level of a full network consisting of several millions of publications and to then gradually drill down into this network until a small subnetwork has been reached including no more than, say, 100 publications, all dealing with a specific topic of interest. (Van Eck \& Waltman, 2014, p. 02).

According to Van Eck and Waltman (2014), CitNetExplorer can assist in the study about the development of a research field or describe the literature on specific topics. The authors point out that it is an analysis of direct citation networks, so, it differs from CiteSpace (Chen, 2006) that operates with co-citations networks. Considering the specificities, we used more than one software to expand the analysis and visualizations of the networks, and, then, increase the capacity to identify the tendencies of research on public opinion. 


\section{RESULTS AND DISCUSSION}

\subsection{Research front (sample of articles from Web of Science)}

Considering the period from 1945 to 2016, we found an initial phase with few publications: two articles were published in 1945, one in 1946 and another two in 1947. A progressive and continuous growth in publications with focus on the term "public opinion" only began in 1956, as shown in Figure 2. In the Figure, we also include a graph in which the total of years was divided into 4 intervals of 17 years each - other analyses are shown later considering these timeframes. Despite some oscillations from one year to another, with increases followed by reductions and new increases, the overall trend was of growth, particularly from 2011 onwards. We noted that at the end of the 1990s there was a slight tendency towards fewer articles, going from 67 in 1998 to 45 in 1999, 42 in 2000 and 35 in 2001 - with growth returning in 2002 (43 articles) and 2003 (48 articles). We noticed that 2015 was the year with the most articles, totaling 175. In 2016 (research was carried out on September 19, 2016) 114 articles have already been published, exceeding the total number of articles published in 2014 and 2013.

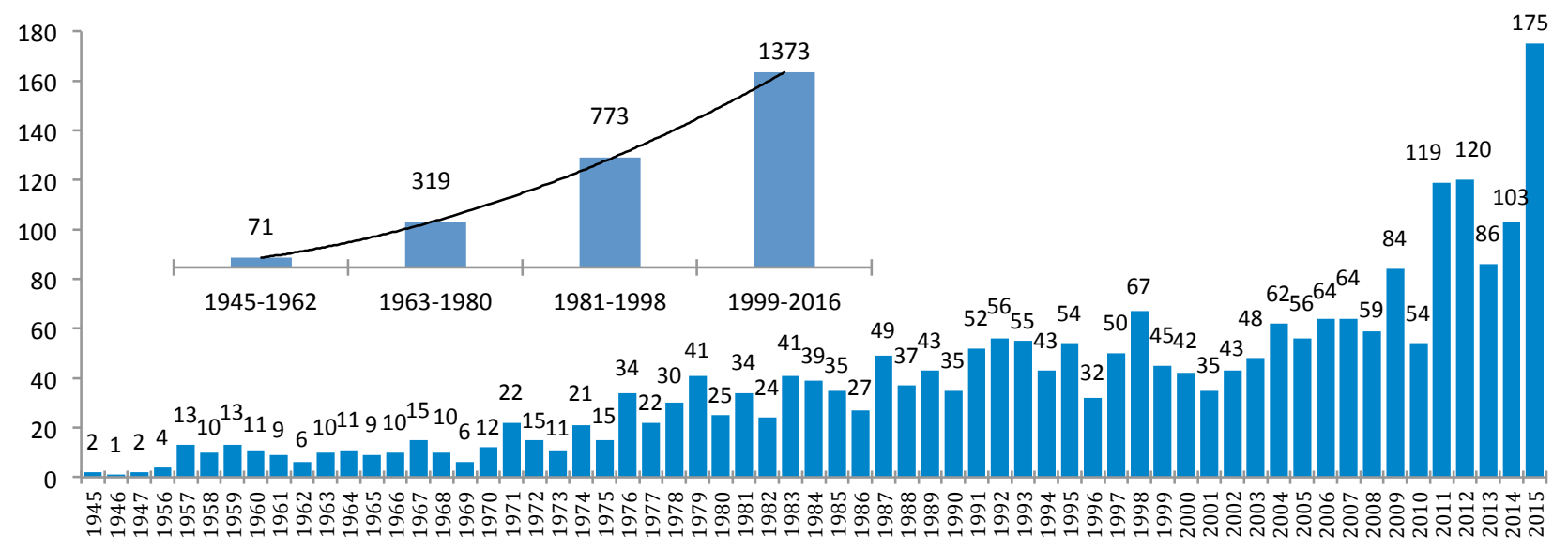

Figure 2 - Evolution and trend of publications per year (1945-2016).

The increase in the number of articles opens space for the diversity of areas, interests and correlated research themes, stressing the plurality of sense attributed to "public opinion", as mentioned by Figueiredo and Cervellini (1995) when addressing the concepts of the term. These are the first indications that the research front of publications on public opinion is quite diversified in theoretical and methodological terms. Nevertheless, the fact the theme is of interest to various areas is not new, having been strengthened by articles that deal with elections (Campbell, 1960; Mueller, 1973), the effects of public opinion on public policies (Page \& Shapiro, 1983; Burstein, 2003) and mass media (Lippmann, 1922; Zaller, 1992). The first two articles found in this search address the issue of the statistical and mathematical measurement of public opinion - text Mann (1945) is indexed in the category of Statistics \& Probability and Mathematics, in Web of Science, and Hyman (1945) is indexed in Psychology.

In the researched samples, the pioneering works were On a problem of estimation occurring in public opinion polls, by Mann (1945), published in the journal Annals of Mathematical Statistics, and Community background in public opinion research, by Hyman (1945), published in the Journal of Abnormal and Social Psychology. Both are from 1945 (the first 
year available for searching Web of Science). Mann (1945) discusses properties of voter number estimation, considering a survey performed in the molds of simple random or stratified sampling. Also along the lines of quantitative studies on public opinion, Hyman (1945) identifies advances and shortfalls in the field of research on public opinion at that time.

Even with the growth observed in Figure 2, we find that for Bornmann and Mutz (2015), there is a growth of science that is from $8 \%$ to $9 \%$ in the second half of the 20th century. We chose to calculate the rate through an autoregressive process of order $p=1$ (Morettin \& Toloi, 2006). In this process, we compared the annual volume of publications against a linear tendency, to verify the growth rate presented by the theme over the studied period. For this case, the growth rate found was $8.64 \%$. If compared with Bornmann and Mutz's paper (2015), it shows that the studied field is within the growth rate of science. Therefore, despite the verified growth, this growth is not higher than the growth rate of science as a whole.

Next, we sought to identify, among the 2,536 sample articles (citing articles), which authors had published the most, especially the existence of authors who have published more than one article from those selected in the sample - these authors are important to demarcate the research front of the field. As such, Table 1 highlights the authors who have published seven or more articles, regardless of the authorship order, also presenting the article most cited in Web of Science (WoS)for each of the authors and the journal in which it was published. The № column denotes the total of articles published per author, and the number of citations is also indicated under Cit., including the most cited article. It is worth noting that the 11 authors shown in Table 1 have articles they co-authored amongst themselves. In this sense, the sum of their publications is 86 articles.

Table 1 - Most prolific authors and their respective most cited articles (Web of Science)

\begin{tabular}{|c|c|c|c|c|}
\hline \multirow{2}{*}{ Author } & \multirow{2}{*}{ № } & \multicolumn{2}{|c|}{ Author's most cited articles (Web of Science) } & \multirow[b]{2}{*}{ Cit. } \\
\hline & & Article & Title & \\
\hline Shapiro, R. Y. & 12 & Page and Shapiro - 1983 & Effects of public-opinion on policy & 499 \\
\hline Jacobs, L. R. & 10 & Jacobs - 1992 & $\begin{array}{l}\text { The recoil effect: public opinion and policymaking in the U.S. and } \\
\text { Britain }\end{array}$ & 29 \\
\hline Brewer, P. R. & 9 & Brewer - 2003 & $\begin{array}{l}\text { Values, political knowledge, and public opinion about gay rights: } \\
\text { A framing-based account }\end{array}$ & 79 \\
\hline Druckman, J. N. & 9 & Chong and Druckman - 2007 & Framing public opinion in competitive democracies & 180 \\
\hline Jacoby, W. G. & 9 & Jacoby -2000 & Issue framing and public opinion on government spending & 152 \\
\hline Glynn, C. J. & 7 & Glynn and Mcleod - 1984 & Public opinion du jour: an examination of the spiral of silence & 48 \\
\hline Herbst, S. & 7 & Herbst - 1993 & $\begin{array}{l}\text { The meaning of public opinion: citizens' constructions of } \\
\text { political reality }\end{array}$ & 20 \\
\hline Kincaid, J. & 7 & Cole and Kincaid - 2000 & $\begin{array}{c}\text { Public opinion and American federalism: Perspectives on taxes, } \\
\text { spending, and trust: An ACIR update }\end{array}$ & 20 \\
\hline Lang, K. & 7 & Lang and Lang - 1978 & $\begin{array}{c}\text { Immediate and delayed responses to a carter-ford debate: } \\
\text { assessing public opinion }\end{array}$ & 18 \\
\hline Page, B. I. & 7 & Page and Shapiro - 1983 & Effects of public-opinion on policy & 499 \\
\hline Price, V. & 7 & Price - 1989 & $\begin{array}{c}\text { Social identification and public opinion: effects of } \\
\text { communicating group conflict }\end{array}$ & 63 \\
\hline
\end{tabular}

Note: The table shows the authors who have published seven or more articles. "Most cited article" refers to the author's most cited article, either authored or co-authored, in the WoS. "Cit." refers to the sum of the article's citations in the WoS database. 
Given a sample of 2,536 articles, the result suggests a fragmentation in the scenario of authors being published on this issue, that is, there are many researchers interested in the theme and reflecting on it, albeit without a central author in the field's research front. However, it is worth mentioning that the authors shown could have other articles and texts on the theme not considered because they are not indexed in Web of Science - Main Collection.

Even without authors who comprise a divergent volume of publications, we can highlight, from Table 1, the authors Robert Y. Shapiro (12 articles) and Lawrence R. Jacobs (10 articles), who have co-authored articles. Shapiro is a professor and researcher linked to the Department of Political Science at Columbia University. He is a specialist in American Politics, working on the themes of: interests of public opinion, policy formulation, political leadership, and means of communication and application of statistical methods. He is also co-author and co-editor of several books and articles published on these themes, such as the Oxford Handbook of American Public Opinion and the Media (edited with Lawrence R. Jacobs, Oxford University Press 2011). It should be stressed that Shapiro has been published on this subject for many years, as author and co-author, with articles spanning from 1983 (Page \& Shapiro, 1983) to 2011 (Shapiro, 2011) and 2013 (Newport et al., 2013). Jacobs also has many years of experience in researching the theme, with special mention for his work in the 1980s (Jacobs \& Shapiro, 1989) and after 2010 (Jacobs \& Mettle, 2011).

In the above list of authors that have published the most, it is important to stress that they are all linked to North American institutions. Of the ten institutions of learning that most publish, all are North American, with special mention for University of California, University of Michigan, University of North Carolina, University of Wisconsin, Columbia University and Florida State University. In the light of this, we also sought to analyze the countries with the highest number of publications (this analysis only considers the country of the first author). As shown in Figure 3, the United States is far ahead in terms of the number of publications.

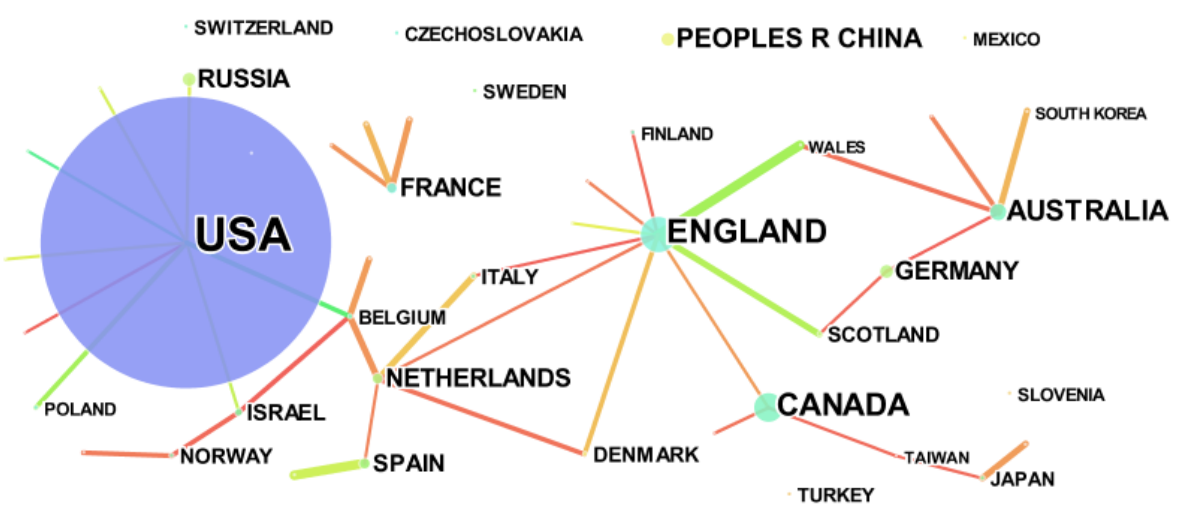

Figure 3 - Network of co-authors' countries (country of first author).

Although other countries have published on the theme, such as England (116 articles), Canada (92 articles), Australia (59 articles), China (44 articles), Germany (42 articles), Russia (4 articles), Holland (36 articles), France (35 articles) and Spain (32 articles), the number of North American articles is far superior to the other countries (914 articles), which is illustrated by the size of the blue sphere in Figure 3. This result corroborates the assertion by Figueiredo and 
Cervellini (1995) on the prominence of North American research on the theme of public opinion, especially in its study and measurement. Therefore, results prove the predominance of the United States on the public opinion research front.

From the United States (the country with the highest number of articles), the most cited works were by the authors, Gamson, Page and Nowak, with their respective articles: Gamson and Modigliani (1989), with 1,108 citations; Page and Shapiro (1983), with 499 citations; and Nowak, Szamrej and Latane (1990), with 320 citations. As per the analysis that will be described later, these articles appear among the 10 most cited from the sample (citations in Web of Science). Also in relation to the United States, the first article found in the search was published in 1947: Public opinion measurement as an instrument in public health practice (Calver \& Wingo, 1947), in the American Journal of Public Health and the Nations' Health.

Continuing the analyses of the articles from the sample, in Table 2, we highlight the 10 most cited articles (number of citations informed through Web of Science). Apart from the title of the articles, Table 2 shows the authors (Citation), the journal in which the article was published and the number of citations (Cit.).

Among the results, it is worth noting that 4 of the 10 most cited articles are from the 1980 s and focus on themes such as the effects of public opinion (Page \& Shapiro, 1983; Page et al., 1987), media and public opinion (Gamson \& Modigliani, 1989) and the relation between beliefs, values and public opinion (Feldman, 1988). The oldest article is the Spiral of silence: theory of public opinion, by Noelle-Neumann (1974), published in the Journal of Communication. In it, the German political scientist puts forward an often cited theory on public opinion and mass communication, in which he argues that people are afraid of isolation (of being excluded) and therefore prefer not to express their opinions when they are contrary to the majority's (particularly on controversial themes).

Table 2 - The 10 most cited articles (1945-2016) from the sample of 2,536 articles (citations in Web of Science)

\begin{tabular}{|c|c|c|}
\hline Title of article & Citation & Cit. \\
\hline Media discourse and public-opinion on nuclear-power: a constructionist approach & Gamson and Modigliani - 1989 & 1108 \\
\hline Effects of public-opinion on policy & Page and Shapiro - 1983 & 499 \\
\hline Spiral of silence - theory of public opinion & Noelle-Neumann - 1974 & 327 \\
\hline From private attitude to public-opinion: a dynamic theory of social impact & Nowak, Szamrej and Latane - 1990 & 320 \\
\hline Structure and consistency in public-opinion: the role of core beliefs and values & Feldman - 1988 & 281 \\
\hline Public opinion toward immigration reform: The role of economic motivations & $\begin{array}{l}\text { Citrin, Green, Muste and Wong - } \\
1997\end{array}$ & 262 \\
\hline Gender gaps in public opinion about lesbians and gay men & Herek - 2002 & 229 \\
\hline Issue frames and group-centrism in American public opinion & Nelson and Kinder - 1996 & 211 \\
\hline What moves public-opinion & Page, Shapiro and Dempsey - 1987 & 211 \\
\hline The impact of public opinion on public policy: A review and an agenda & Burstein - 2003 & 207 \\
\hline
\end{tabular}

The most cited article by far is Media discourse and public-opinion on nuclear-power: $a$ constructionist approach, by Gamson and Modigliani (1989) published in the American Journal of Sociology. This article studies the relation between media and public opinion through an analysis of the discourse on nuclear energy over more than three decades. The intention is to understand 
the formation of public opinion on nuclear energy (Gamson \& Modigliani, 1989). Regarding the journals in which the 10 articles were published, we noted that the majority came from areas related to political science; the themes are also linked to these areas - it is the case of those that deal with influence of public opinion on political decisions (Burstein, 2003; Page \& Shapiro, 1983), on the relation between media and public opinion, the impacts of public opinion, the relation of public opinion to beliefs and values, as well as looking at themes such as immigration and homosexuality, among others. Therefore, we reiterate that our analysis of the research front showed the existence of a plurality of themes, approaches and empirical research on public opinion, with a strong presence of themes related to the area of political science. In addition, on the research front, the article by Gamson and Modigliani (1989), on media and public opinion in the case of nuclear energy, stands out.

Next, we list the most frequent journals in the 2,536 published articles from the sample. This assessment was aimed at identifying any journal that was notable for the publication of articles on public opinion. In the list, we found a very high number of journals - more than $960-$ demonstrating that the publications are disperse, being distributed between different journals, focused on wide-ranging areas (including political science, communication, economics, history, environmental sciences, health sciences, technology, engineering, literature, international relations, public policy, demography, public administration, business and others). Considering the journals from Table 3, the following published more than 30 articles: Public Opinion Quarterly (128 articles), Sotsiologicheskie Issledovaniya (73 articles), International Journal of Public Opinion Research (56 articles) and American Journal of Political Science (40 articles).

Table 3 - Journals that published the most articles from the sample (1945-2016)

\begin{tabular}{lccc}
\hline \multicolumn{1}{c}{ Journal } & $\begin{array}{c}\text { Frequency } \\
\text { (articles) }\end{array}$ & Proportion (partial) & Proportion (total) \\
\hline Public Opinion Quarterly & 128 & $30.12 \%$ & $5.05 \%$ \\
Sotsiologicheskie Issledovaniya & 73 & $17.18 \%$ & $2.88 \%$ \\
International Journal of Public Opinion Research & 56 & $13.18 \%$ & $2.21 \%$ \\
American Journal of Political Science & 40 & $9.41 \%$ & $1.58 \%$ \\
Journal of Politics & 28 & $6.59 \%$ & $1.10 \%$ \\
Sociologicky Casopis & 22 & $5.18 \%$ & $0.87 \%$ \\
American Political Science Review & 21 & $4.94 \%$ & $0.83 \%$ \\
Political Research Quarterly & 20 & $4.71 \%$ & $0.79 \%$ \\
Journalism Quarterly & 19 & $4.47 \%$ & $0.75 \%$ \\
Political Science Quarterly & 18 & $4.24 \%$ & $0.71 \%$ \\
\hline Partial sum of the articles & $\mathbf{4 2 5}$ & $\mathbf{1 0 0 . 0 0 \%}$ & $\mathbf{1 6 . 7 6 \%}$ \\
\hline Other articles & $\mathbf{2 1 1 1}$ & $\mathbf{8 3 . 2 4 \%}$ \\
\hline Total of articles & $\mathbf{2 5 3 6}$ & $\mathbf{1 0 0 . 0 0 \%}$ \\
\hline
\end{tabular}

Table 3 shows that the first 10 journals represent just $16.76 \%$ of publications, showing that the articles from the sample came from a very large number of journals. Nevertheless, the journals with the highest number of articles demonstrate a relative concentration of research on public opinion in areas linked to political sciences (American Journal of Political Science, Journal of Politics, American Political Science Review and Political Research Quarterly), or are journals 
specialized in public opinion, such as Public Opinion Quarterly and the International Journal of Public Opinion Research. As such, these are the characteristics of the research front in terms of journals.

In terms of the sheer number of articles, the Public Opinion Quarterly stands out. It has a high impact factor, was created in 1937 and is part of the Oxford University publications. The journal's publications deal with theoretical contributions to communication research, public opinion analysis and the investigation of methodological questions (Public Opinion Quarterly, 2016). In this journal, the most cited article was Gender gaps in public opinion about lesbians and gay men by Herek (2002), with 229 citations, and the oldest article was Public-opinion and national-security policy by Almond (1956). Herek (2002) analyzed the disparity in attitudes among heterosexuals in relation to homosexuals. The results showed that heterosexual men had less favorable attitudes towards homosexuals in terms of gender issues. The author's research fits the orientation of opinion surveys. Almond's research (1956) concerned public opinion and national security.

Through the analysis of Bibliographic Couplin in the VOSviewer, we identified 5 clusters in the journals where the articles of the sample were published (Figure 4).

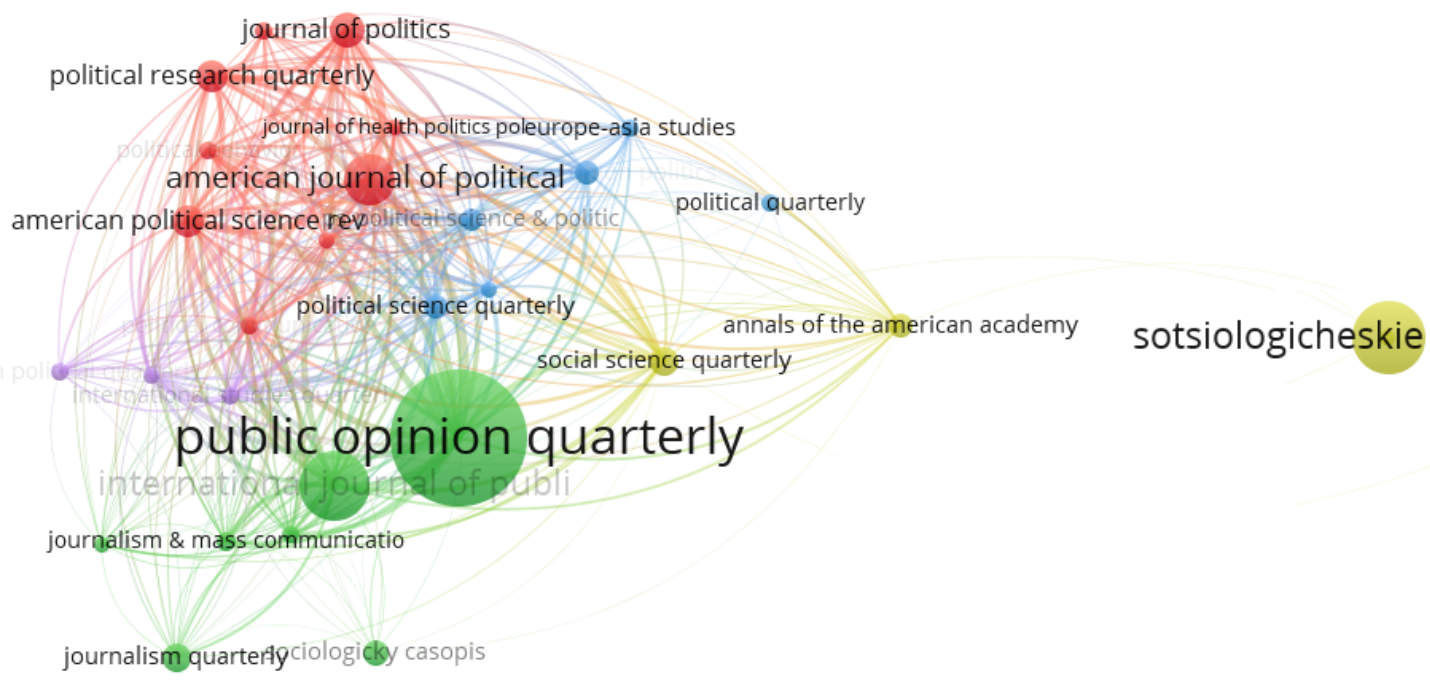

Figure 4 - Analysis of bibliographic couplin (cut of at least 10 articles).

Cluster 1 (red) consists of 9 journals. In this cluster, journals with more articles in the sample are: American Journal of Political, American Political Science and Journal of Political Science. Most of the journals in this cluster are focused on discussions about the field of political science. Cluster 2 (green) consists of 7 journals. This cluster is more focused on publications in the areas of journalism and media with journals such as Journalism and Mass Communication Quartely, Communication Research and Journalism Quartely. The journal with more articles in this cluster is Public Opinion Quarterly - it is the journal with the largest number of articles in the sample.

Cluster 3 (blue) consists of 6 journals, among them, Europe-Asian Studies, Political Quartely, European Union Politcs and Political Science Quartely. In general, they are journals from the political science field. Cluster 4 (yellow) consists of 4 journals: Annals of the American 
Academy of Political and Social Science, Russian Political and Law, Social, Science Quartely and Sotsiologicheskie Issledovaniya - the last one is the second journal in number of articles in the sample. Finally, cluster 5 (purple) consists of 3 journals: International Studies Quartely, Journal of Conflict Resolution and Western Political Quartely.

In Figure 5, we show the distribution of articles by categories in Web of Science (only areas of frequency equal to or greater than 44 appear in the figure). Indexation by categories shows that the theme of public opinion is multidisciplinary, even though it is mostly associated with Government and Law (844 articles), followed by studies in the areas of Political Science (780) and Communication (353). It is noteworthy that apart from the areas of knowledge cited, there are publications in various other areas of the sciences, such as medicine, art, cultural studies, international relations, education, environmental sciences, statistics, mathematics, business, demography, geography and ethics.

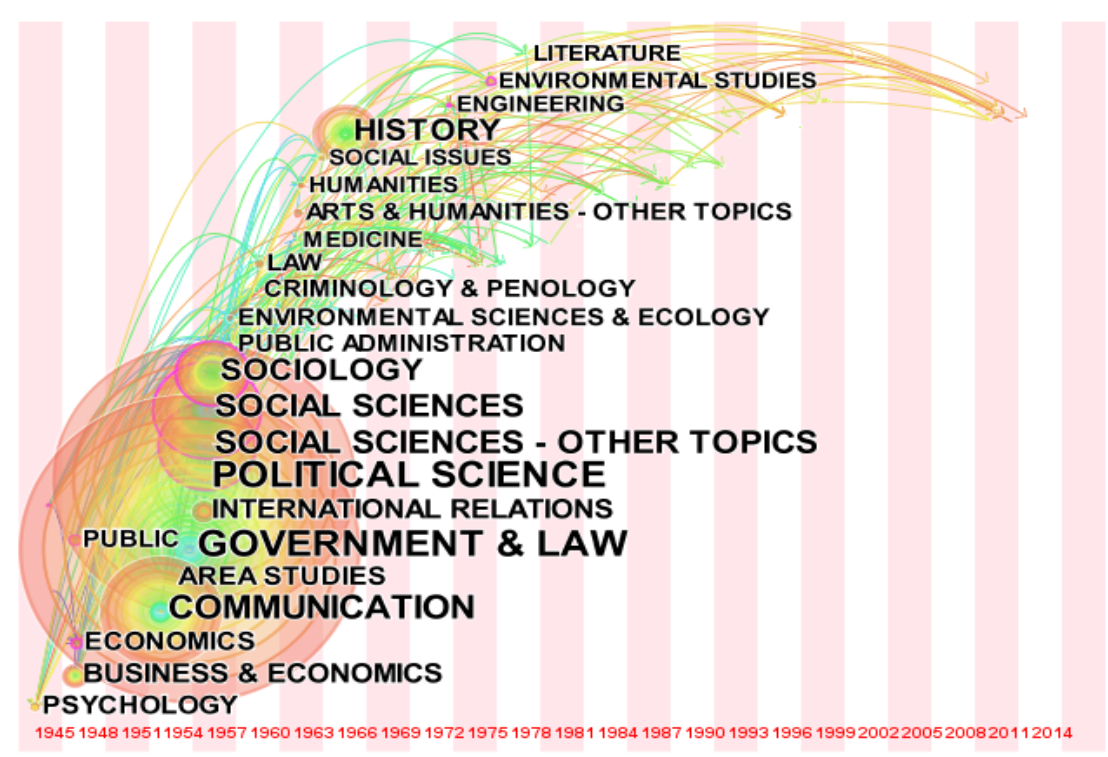

Figure 5 - Co-occurring subject (Web of Science Category).

The co-occurring subject above is presented in the time zone format (Chen, 2006), showing, apart from frequency of articles (marked by the size of the circles), the trend for field expansion (marking the positions in which the first article from each area was published). It demonstrates that the research front has expanded and today forms a multidisciplinary field (exact and earth sciences; human sciences; agrarian science engineering and applied social sciences), as Figueiredo and Cervellini (1995) also point out.

In general, we noticed that the texts already presented also stand out in this aspect, such as the article by Page and Shapiro (1983), which is indexed both in the Government \& Law category, and also in Political Science. The article (Communication) by Gamson and Modigliani (1989), the most cited from our sample, also appears, as well as the classic article by NoelleNeumann (1974). It is worth mentioning that the articles indexed in the category of History are little cited - the most cited article in this category was referenced only 32 times. Next, we will analyze the keywords used (co-occurring keywords), shown in Figure 6. 


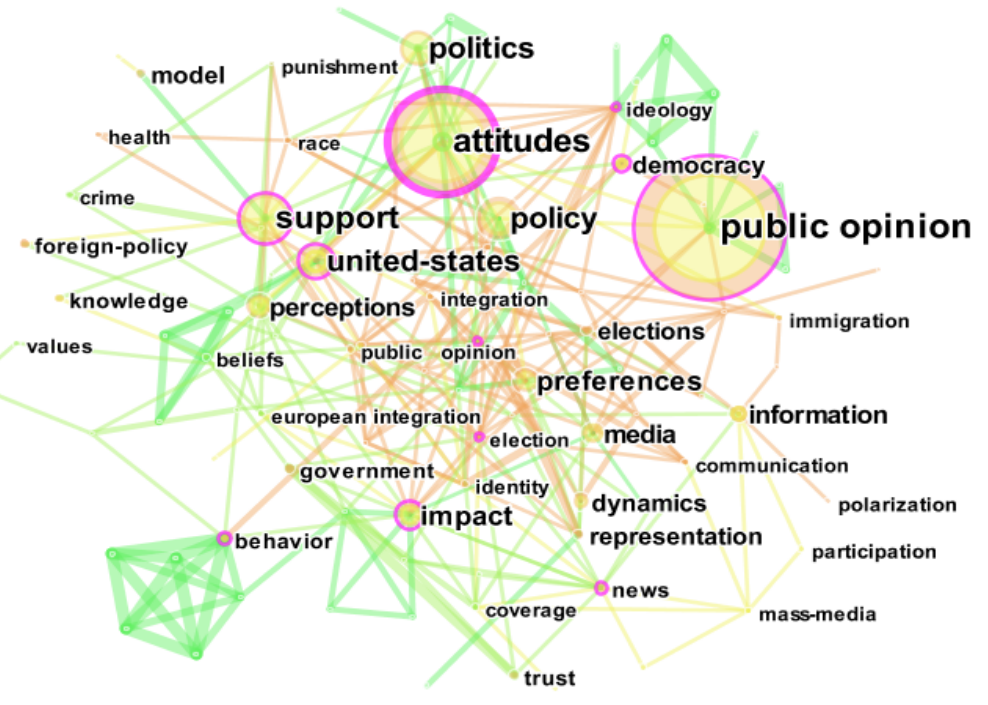

Figure 6 - Co-occurring keywords (Years per slice $=10$ ).

The most frequent keyword was public opinion, used 333 times (which was expected given the field demarcation). After it came attitudes (235), support (126), policy (118), among others, as per Figure 6 and Table 4. The highlighted words comprise the subject areas of the research front and, therefore, indicate focuses and trends in public opinion research (in the network those with frequency of at least 20 times were highlighted). Table 4 shows the frequency of keywords and the most cited article that used the respective keyword. We noted that the words and articles again demonstrate the plurality of the field and the multiplicity of research carried out from different study perspectives.

Table 4 - Top 10 co-occurring key-words

\begin{tabular}{|c|c|c|c|}
\hline \multirow{2}{*}{ Key-word } & \multirow{2}{*}{ Freq. } & \multicolumn{2}{|r|}{ Most cited article that used the respective keyword } \\
\hline & & Author & Article \\
\hline public opinion & 333 & $\begin{array}{l}\text { Firestone and Kempton - } \\
\qquad 2007\end{array}$ & Public opinion about large offshore wind power: underlying factors \\
\hline attitudes & 235 & $\begin{array}{l}\text { Citrin, Green, Muste and } \\
\text { Wong - } 1997\end{array}$ & Public opinion toward immigration reform: the role of economic motivations \\
\hline support & 126 & Hooghe and Marks - 2005 & $\begin{array}{l}\text { Calculation, community and cues } \\
\text { public opinion on European integration }\end{array}$ \\
\hline policy & 118 & Jacoby - 2000 & Issue framing and public opinion on government spending \\
\hline United-States & 103 & Burstein - 2003 & The impact of public opinion on public policy: a review and an agenda \\
\hline politics & 96 & $\begin{array}{l}\text { Citrin, Green, Muste and } \\
\text { Wong - } 1997\end{array}$ & Public opinion toward immigration reform: the role of economic motivations \\
\hline impact & 73 & $\begin{array}{l}\text { Chong and Druckman - } \\
\qquad 2007\end{array}$ & Framing public opinion in competitive democracies \\
\hline preferences & 72 & Jacoby - 2000 & Issue framing and public opinion on government spending \\
\hline perceptions & 62 & $\begin{array}{l}\text { Brulle, Carmichael and } \\
\text { Jenkins - } 2012\end{array}$ & $\begin{array}{l}\text { Shifting public opinion on climate change: an empirical assessment of } \\
\text { factors influencing concern over climate change in the U.S., 2002-2010 }\end{array}$ \\
\hline media & 62 & Cobb - 2005 & Framing effects on public opinion about nanotechnology \\
\hline
\end{tabular}


In the selection of the articles published, besides the natural predominance of the term 'public opinion' (333 times) - the theme of this paper - we observed a network of words that could be connected to more frequent categories of the articles. Information, news and media, for example, are strongly related to the area of Communication. And policy, election, representation, democracy and politics are common terms in Political Science studies, as well as Government and Law. Attitude is one of the most used expressions among the keywords ( 235 times) and may be linked to studies from different areas and categories. Perhaps it is used so much due to its relation to the term opinion, taken to mean a personal attitude involving choices (Borges, 2014; Mateus, 2008). Other keywords indicate conceptual studies on public opinion, its impacts (measurement) or "public opinion survey", such as support, knowledge, model, dynamics, behavior, impact and perception. Other keywords suggest more specific empirical research contexts, such as war, immigration and foreign policy. It is worth noting that the term United States is the fifth most used keyword, linked to the fact that it is the country with the highest number of studies on public opinion, has a tradition of carrying out surveys in this area and is where the authors publish the most.

Another analysis performed in the CiteSpace software from the keywords network was through the function of grouping words in clusters. Clusters reveal underlying groups and make it possible to find categories that directly support analysis (Chen, Ibekwe-SanJuan \& Hou, 2010). Clusters (Figure 7) were formed by the keywords network, using a selection and comparison algorithm. For tagging automatic cluster, we chose to select the tags directly from the index terms of articles cited in each cluster. In order to characterize the nature of clusters, we used two algorithms for classification, log-likelihood tests (LLR) and mutual information tests (MI) (Dunning, 1993; Chen, 2012). According to Chen, Ibekwe-SanJuan, Hou (2010, p. 2) "the traditional cocitation analysis typically focuses on cited members of clusters as a primary source of evidence for interpretation. Focusing on citers can improve our understanding of the nature of a research front and its intellectual base". Thus, as shown in Figure 7, there are 7 co-citation clusters in the network and these clusters are labeled by index terms from their own citers.

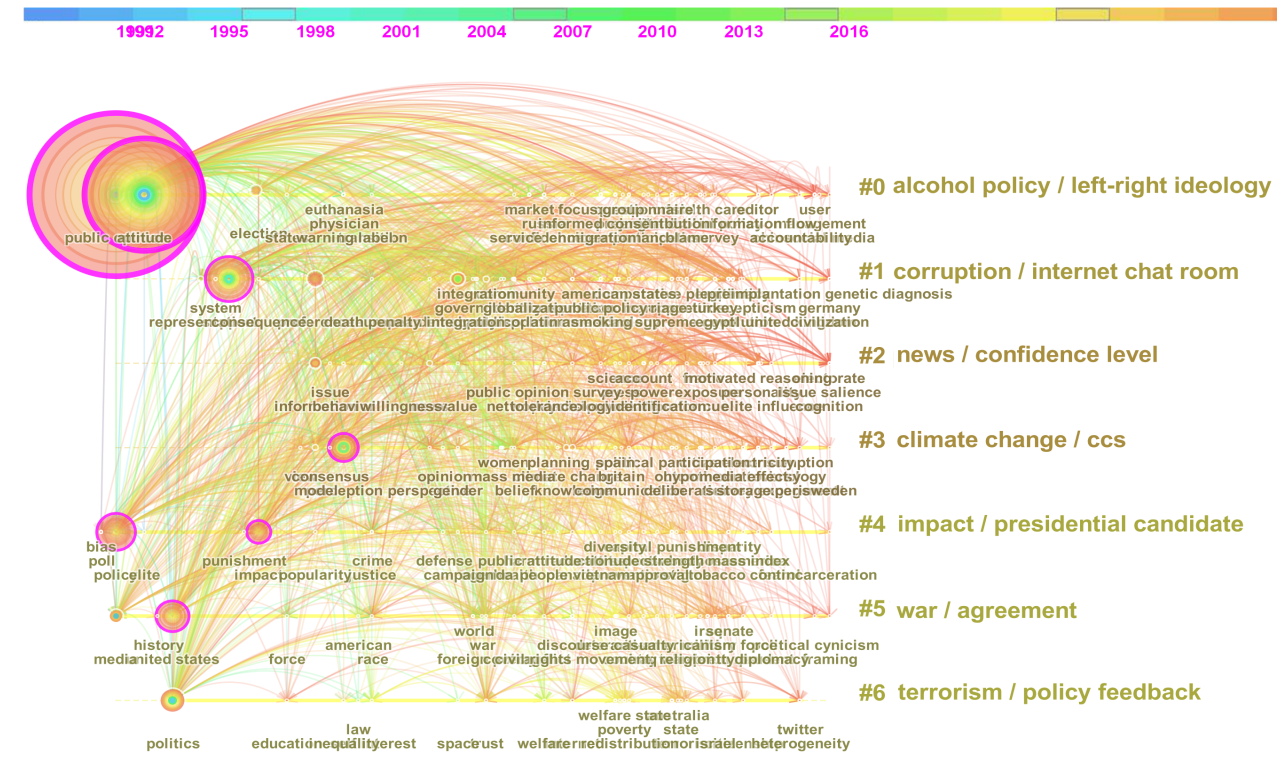

Figure 7 - Cluster analysis in the network of co-occurring keywords. The best consensus-conforming ranking methods: 1 ) index terms by LLR = log-likelihood tests; 2 ) index terms by $\mathrm{MI}=$ mutual information tests. 
Hence, the procedure extracted 7 clusters, being the largest one with 56 articles. Clusters do not come with the labels: cluster 0 (alcohol policy/letf-right ideology), cluster 1 (corruption/internet chat room), cluster 2 (news/confidence level), cluster 3 (impact/presidential candidate), cluster 5 (war/agreement) and cluster 6 (terrorism/policy feedback). Figure 8 shows the cluster $(C)$, the size (number of articles) and the main words.

\begin{tabular}{|c|c|c|}
\hline C & SIZE & LABEL \\
\hline 0 & 56 & $\begin{array}{l}\text { public opinion; alcohol policy; national drug strategy household survey; beverage container; } \\
\text { warning label; text analysis; authoritarianism; agenda setting; incumbency advantage; content } \\
\text { analysis; online public opinion; accessibility; community survey; geosocial media. }\end{array}$ \\
\hline 1 & 55 & $\begin{array}{l}\text { public opinion; policy responsiveness; ideological congruence; budget speeches; single-party } \\
\text { majority governments; government stability; intra-party politics; hierarchical model; european } \\
\text { integration; behavior; representation; interest groups; mobilisation; vector autoregression; } \\
\text { candidate evaluation. }\end{array}$ \\
\hline 2 & 44 & $\begin{array}{l}\text { public opinion; resource allocation; liver transplantation; agenda setting; biotechnology; policy } \\
\text { issue; accessibility; attitudes; public opinion surveys; competition; information; accessibility; } \\
\text { ambivalence; belief content; belief importance; framing effects. }\end{array}$ \\
\hline 3 & 42 & $\begin{array}{l}\text { public opinion; communication; urban space; holy roman empire; printing culture; publishing } \\
\text { industry; presence; culture; foods; climate change; information; participation; nanotechnology; } \\
\text { controversy; city public; political parties; city transport. }\end{array}$ \\
\hline 4 & 36 & $\begin{array}{l}\text { public opinion; television news; candidate evaluation; agenda setting; civil right; redistribution; } \\
\text { advertising; explanation. }\end{array}$ \\
\hline 5 & 33 & $\begin{array}{l}\text { public opinion; television news; body worlds; authoritarianism; collective preferences; public } \\
\text { opinion surveys; audience cost; states; issue ownership; audience cost; racial attitudes; education } \\
\text { system. }\end{array}$ \\
\hline 6 & 25 & $\begin{array}{l}\text { public opinion; income distribution; critical theory; selective exposure; political participation; } \\
\text { agenda setting; accessibility; nonresponse bias; attitudes; political sociology; social policy; } \\
\text { comparative politics; public expenditures. }\end{array}$ \\
\hline
\end{tabular}

Figure 8 - Cluster labels.

In general, clusters enlarge the researched topics on public opinion. Methodological issues emerged, such as survey, analysis models (text analysis, content analysis), statistical methods (regression and others), bias, and public opinion research, among others. There were also broad themes such as configuration of the political agenda, attitudes, framing effects, communication, political sociology, representation, interest groups, culture, collective preferences, controversies, civil law and participation. As specific topics, in the clusters there are: critical theory, public expenses, accessibility, budget speeches, government stability, European integration, climate change, nanotechnology, political parties, propaganda, racial attitudes and education systems.

To test other representations and understand groups of keywords in other ways, we built the keyword co-occurrence network in the software VOSviewer 1.6.7. Through this process, it was possible to visualize 5 clusters in 61 keywords (Figure 9). 


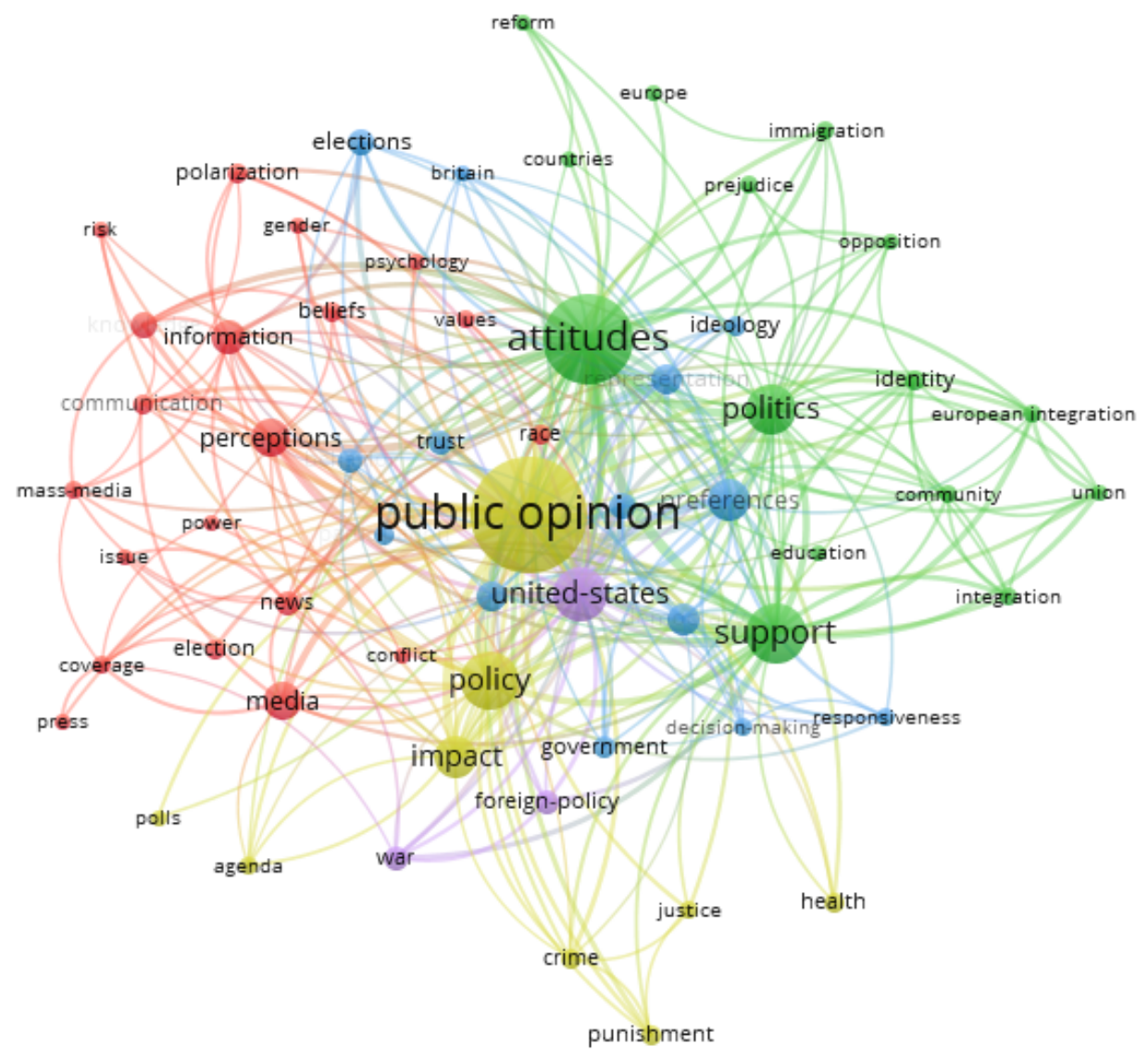

Figure 9 - Keywords co-occurrence Network (frequency of at least 15 keywords).

The largest, cluster 1 (red) consists of 20 words: beliefs, communication, conflict, coverage, election, gender, information, issue, knowledge, mass-media, media, news, perceptions, polarization, power, press, psychology, race, risk and values. This cluster concentrates researches that deal with the relations between communication means in general (media, newspapers, mass-media) and public opinion. It is proved by the highest frequency of the keywords information, perceptions and media. Specific topics of research come up, as gender, race, values and elections.

Cluster 2 (green) has 15 keywords: attitudes, community, countries, education, Europe, European integration, identity, immigration, integration, opposition, politics, prejudice, reform, support and union. The most frequently occurring keywords in cluster 2 are attitudes, support and politics. In this cluster, there are noticeable discussions on how public opinion about issues such as European integration, immigration and reforms have wide media space and academic debate. Cluster 3 (blue) has 14 words: behavior, britain, decision-making, democracy, dynamics, elections, government, ideology, model, participation, preferences, representation, responsiveness and trust. The most frequent is the word preferences. This cluster concentrates research focuses on electoral processes, measures of preferences aggregation, ideologies and the relationship between truth and public opinion.

Cluster 4, in yellow, is formed by 9 items: agenda, crime, health, impact, justice, policy, polls, public opinion and punishment. The most frequent word is public opinion. In this cluster, there are specific research topics such as crime, health, justice and others that gain prominence 
in public opinion. Finally, cluster 5 (purple) is formed only by the keywords foreign-policy, UnitedStates and war. In this cluster, the most frequent word is United-States. According to previous discussion, this country concentrates both the locus of theoretical and methodological dilemmas on public opinion research, including classical works, as well as cases around elections, wars (Vietnam, Iraq, among others), immigrants, the role of media, among other topics in public opinion that are researched in the United States.

In order to broaden the analysis of relevant research themes, we sought to identify more frequent words in the titles and abstracts of the articles of the sample, that according to Figure 10, differentiate in some way from the keywords and, thus, allows new analyzes. Figure 10 was constructed using the software VOSviewer 1.6.7 and with this procedure it was possible to visualize 4 clusters with a total of 81 words.

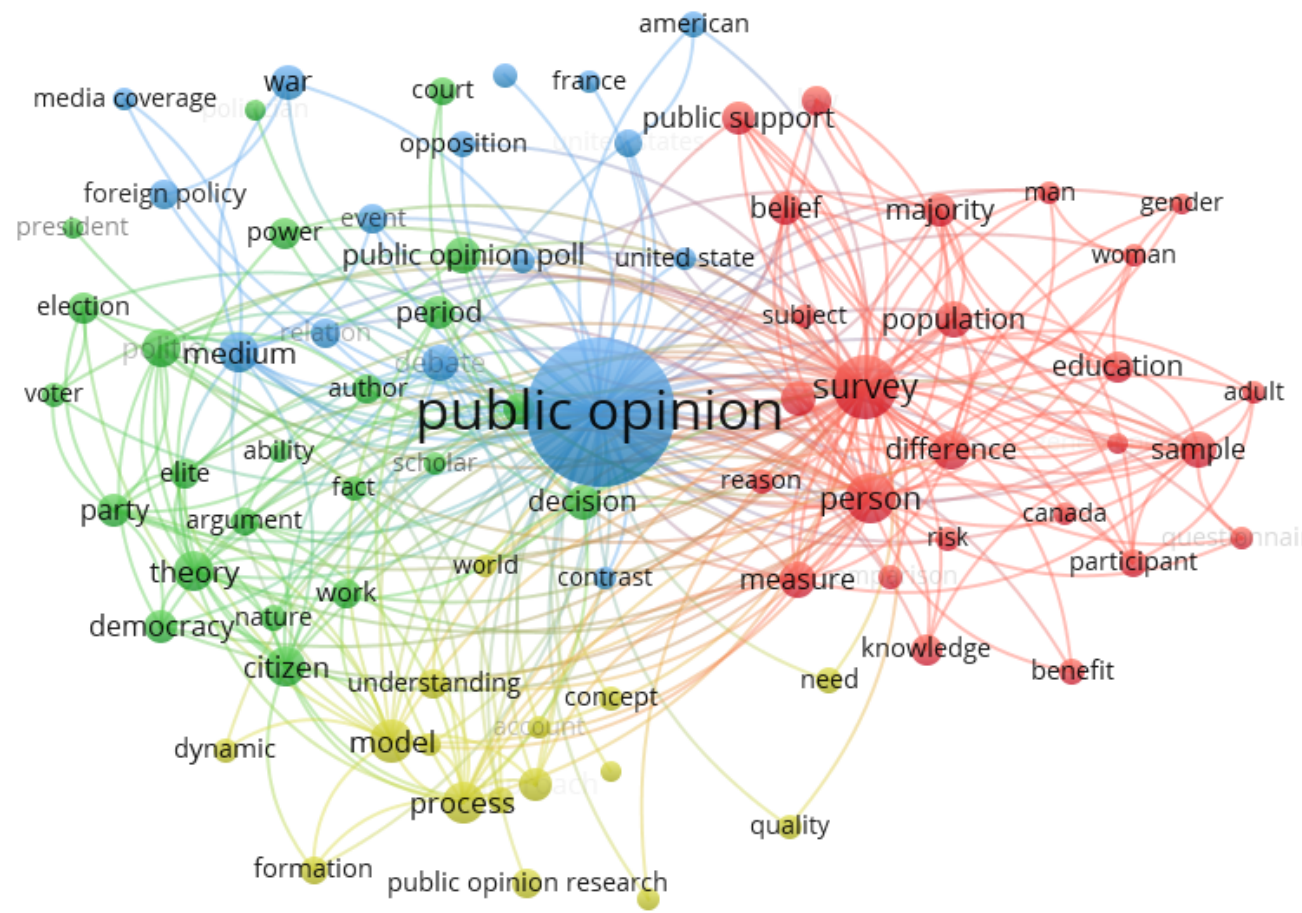

Figure 10 - Network of words occurrence in titles and abstracts (frequency of at least 35).

Cluster 1 (red) has 26 words: adult, belief, benefit, Canada, comparison, difference, education, gender, general public, knowledge, law, majority, man, measure, participant, person, population, public opinion survey, public support, questionnaire, reason, risk, sample, subject, survey, and woman. It comes up new expressions and research topics such as gender, law, woman and beliefs. There are also methodological topics such as sample, questionnaire and survey. This review shows that quantitative methods are still preponderant when looking at public opinion on a given topic.

Cluster 2 (green) has 23 words: ability, argument, attention, author, citizen, court, decision, democracy, election, elite, fact, nature, party, period, politic, politician, power, president, public opinion poll, scholar, theory, voter, and work. Again, it is on evidence public 
opinion works about electoral processes, president, vote, politics and party. There are still topics about decision, nature, power, and theory.

Cluster 3 (blue) consists of 16 words: public opinion, American, American public opinion, contrast, debate, decade, event, foreign policy, France, media coverage, medium, opposition, relation, United State, United States, and war. The most frequent word is public opinion. Finally, cluster 4 (yellow) has 16 words: account, aproach, case study, communication, concept, dynamic, example, formation, model, need, process, public opinion research, public policy, quality, understanding, and world. In cluster 3, there are topics as debate, foreign policy, war, and, two countries: the United States and France. In cluster 4, it shows case study, communication, formation, public opinion polls, among others.

The previous figures ( 9 and 10) showed the diversity of topics that are treated in the scope of public opinion research and illustrated this through bibliometric networks. About software, the procedure performed in VOSviewer proved to be visibly more instructive than the cluster built in CiteSpace. In this research, we have seen that clusters in VOSviewer have better visualization, while in CiteSpace the co-citation cluster makes the understanding process of clusters and labels difficult.

It is important to stress that there are different uses of the public opinion concept. According to Mateus (2008) and Figueiredo and Cervellini (1995), the confusion at the concept of the expression 'public opinion' is also tied to the association it has with opinion surveys. Figueiredo and Cervellini (1995), Habermas (1996) and Borges (2014) claimed that simplistic associations hinder the conceptual understanding of public opinion, since the emergence of opinion poll institutes was guided by an empiricist paradigm, leading to an abandonment of the fundamental concepts of the philosophical-political thinking that founded the concept of public opinion at the beginning of the 19th century. In the context of this debate, Perrin and McFarland (2011) argue that both public opinion researchers and their critics are correct in some aspects. Therefore, discussion of this impasse should entail a revision of the nature of public opinion in order to use research techniques suited to the purpose and to adopt processes for the critical assessment of results.

\subsection{Intellectual Base for the Research into Public Opinion Field}

Continuing with our analysis, we will now evaluate the co-citation networks of journals, authors and references (documents). To broaden our understanding of the journals, through Citespace, the journal co-citation network was created- in this case, journals in which articles from the sample were published are not shown, but rather the journals co-cited by the 2,536 articles analyzed (Figure 11). 


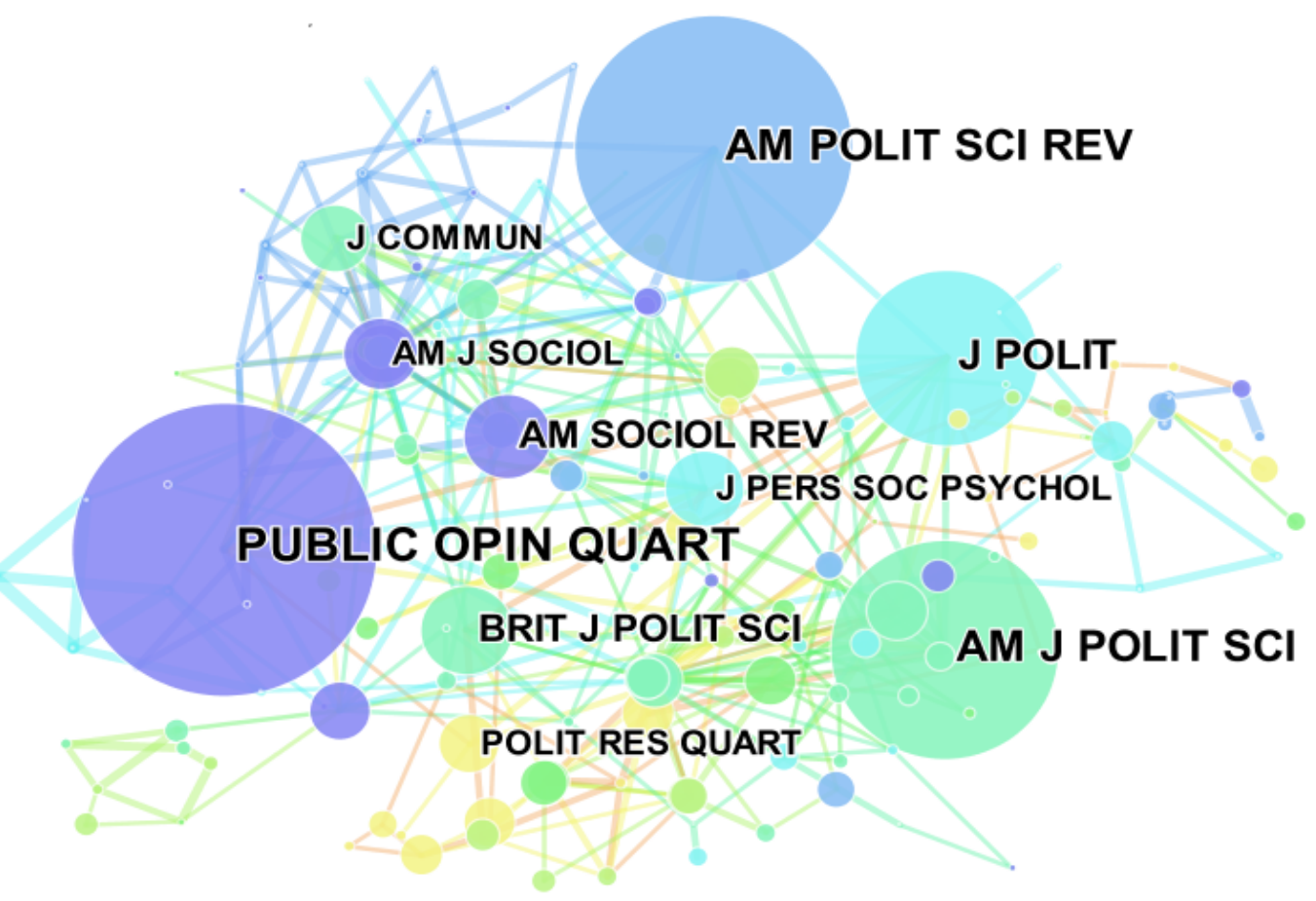

Figure 11 - Journal Co-Citation Network (10-yers per slice).

The network highlights the journals Public Opinion Quarterly and American Political Science Review. Even though it is the journal with the second highest frequency of published articles from the sample, Sotsiologicheskie Issledovaniya does appear prominently in the journal co-citation network. Despite having a high number of published articles, the texts are not cited often (in this journal, the most cited article had only 1 citation). The journals with greatest frequency in the co-citation network are Public Opinion Quarterly (674), American Political Science Review (611), American Journal of Political Science (501), Journal of Politics (405) and British Journal of Political Science (203). Therefore, with the exception of the first, the following three are focused on the area of political science. Other prominent journals in the network are from the area of sociology (American Sociological Review, 194 and American Journal of Sociology, 160), social psychology (Journal of Personality and Social Psychology, 173) and communication (Journal of Communications, 155).

Among the most prolific journals, the oldest reference to the theme is from the American Journal of Sociology, with a citation dating back to 1945. The most recent reference is from Political Research Quarterly, 133, whose first citation was from 1996. In Figure 11, the dark blue colors indicate articles with the oldest references (before 1960) - American Journal of Sociology and Public Opinion Quarterly. Articles referenced predominantly at the end of the 1990s are in yellow (Political Research Quarterly).

Of the journals that feature the most, it is important to remember that Public Opinion Quarterly was already mentioned in this article. American Political Science Review is also a significant journal for research on political science, including publications in the areas of political theory, American politics, public policy, public administration, comparative politics and international relations (American Political Science Review, 2016). It is a publication from the 
American Political Science Association (APSA) and has been continually edited for 110 years (since 1906).

With regard to the journal co-citation network, the intellectual base of the field is marked by the journals Public Opinion Quarterly, American Political Science Review, American Journal of Political Science and Journal of Politics. Despite the presence of journals on different themes and areas of knowledge, the categories of Government and Law and Political Science are those that feature in the magazines with the highest number of articles on public opinion.

In relation to author co-citation networking, we identified the authors who comprise the intellectual base of the field. As shown in Figure12, through the wide circumference of nodes for the theme of public opinion, the highest number of references in the co-citation network comes from the authors, Benjamim I. Page (227) and John R. Zaller (205).

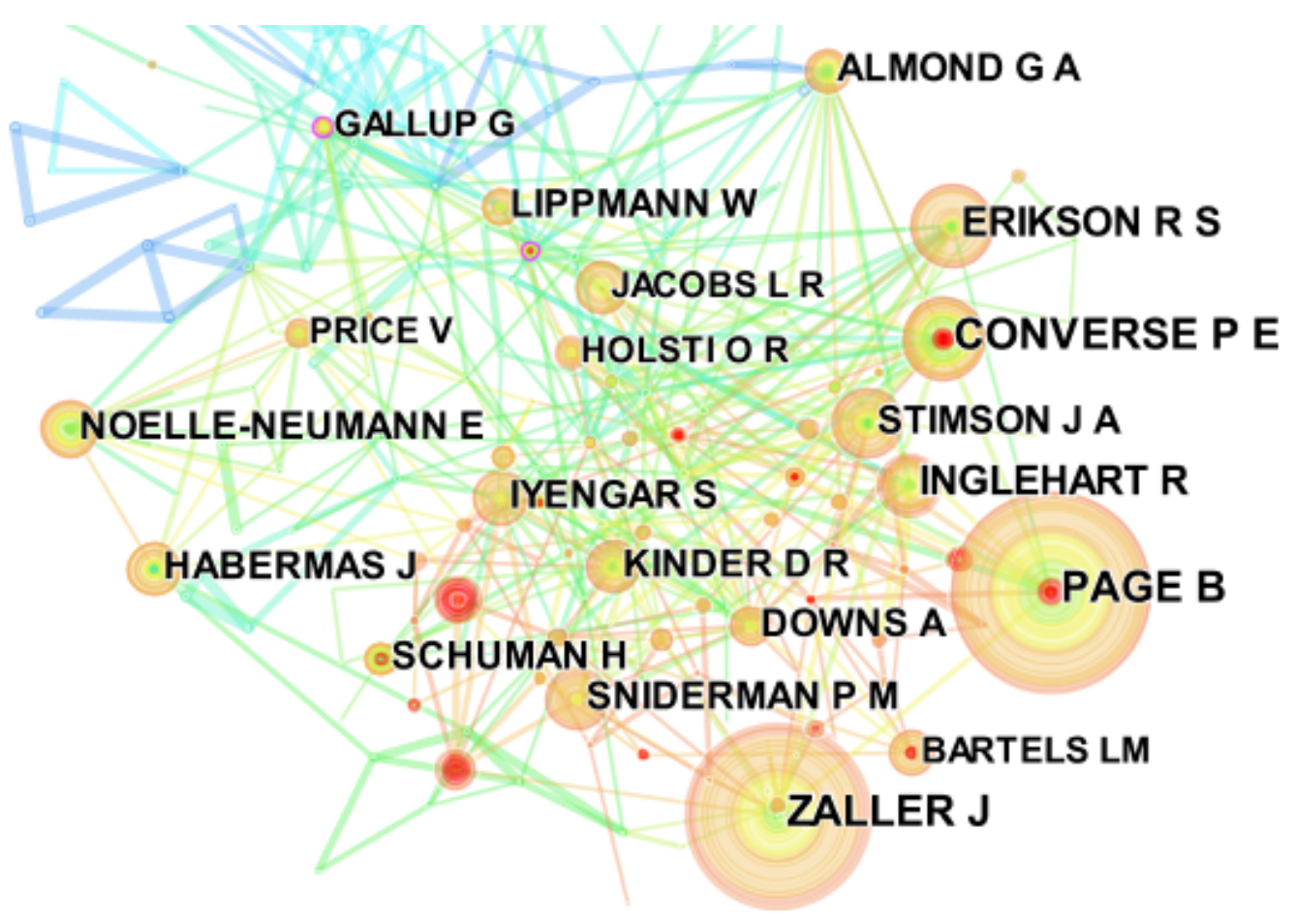

Figure 12 - Author co-citation network (Years per slice = 7).

Colors also denote the authors who were referenced in different periods of time - blue for networks of co-citations from the 1940s and 1950s, with special mention for G. Gallup and W. Lippmann - classic authors in the field who maintain a high number of citations for their work till this day. Phillip. E. Converse is shown in the green part of the network, with work dating back to 1960s, as is Robert S. Erikson, in the 1970s. The authors Page and Zaller are more recent, marked by their work in the 1980s and 1990s respectively - the fact they are more cited could be interpreted based on Chen $(2004,2006)$, who points out that recent texts tend to be cited more and therefore contribute to the increased number of citations.

To bring the intellectual base to life, we prepared a brief profile of two of the main authors. Benjamin I. Page is a professor in the Department of Political Science at Northwestern University (USA). Apart from themes related to public opinion, their research is focused on 
American politics, internal and external policy and economic and political inequality. Among their best known works are: The rational public: Fifty years of trends in Americans' policy preferences, Effects of public opinion on policy and What moves public opinion? - all three in co-authorship with Shapiro. John Zaller is a professor in the Department of Political Science at University of California, Los Angeles (USA). His work covers politics and public opinion. He is best known for his book published in 1992 - The Nature and Origins of Mass Opinion. Other works worth mentioning include: Journalists and Citizens Shape the News; The American Ethos, Public Attitudes Toward Capitalism and Democracy (in co-authorship with Herbert McCloskey).

To better understand the evolution of the field, we evaluated the co-citation networks dividing the period analyzed into 4 intervals of 17 years, as per Figure 13.

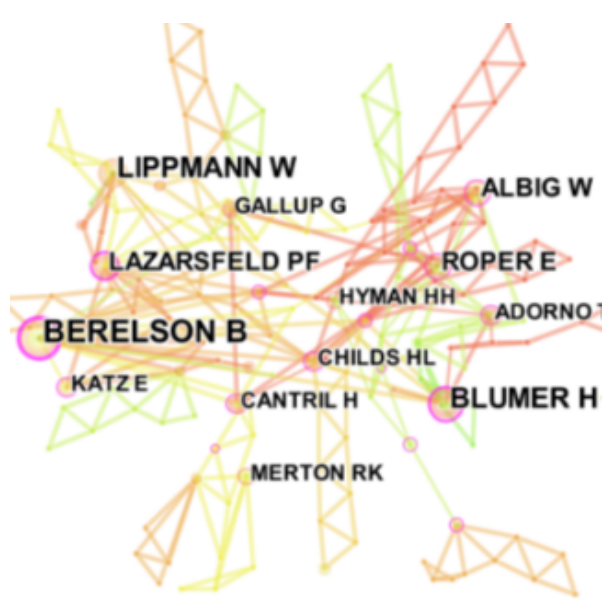

(a) $1945-1962$

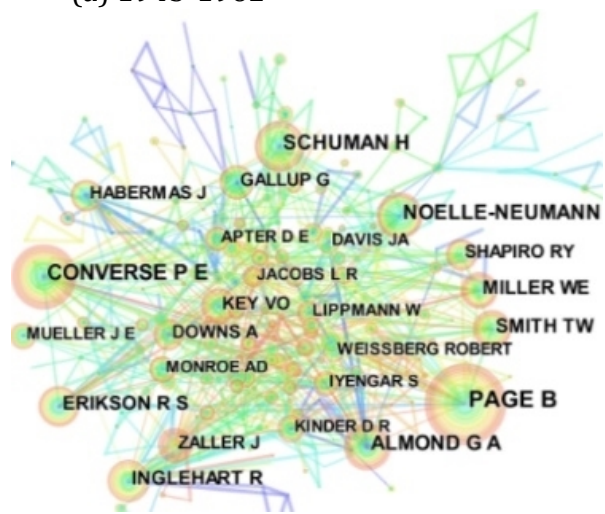

(c) $1981-1998$

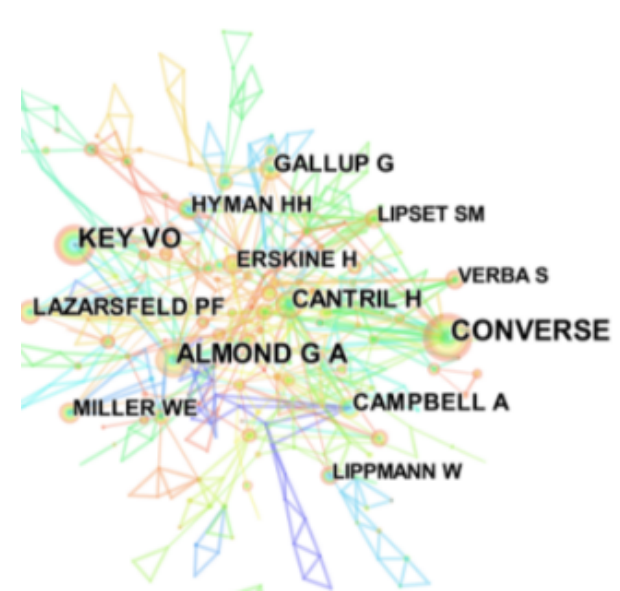

(b) 1963-1980

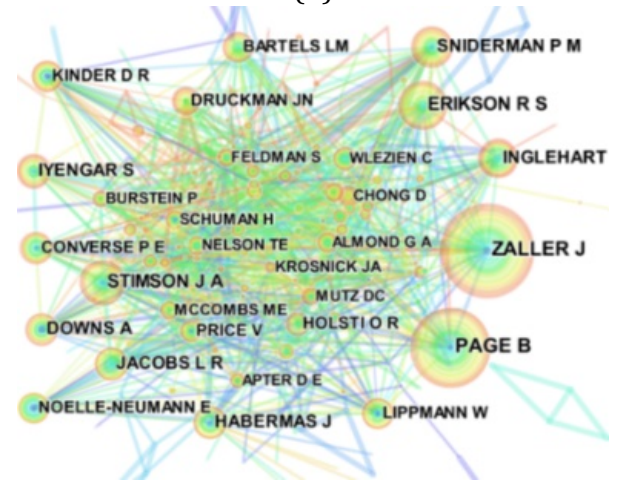

(b) $1999-2016$

Figure 13 - Author co-citation network in 4 periods.

Here we visually represent the expansion of the field in terms of nodes and links, demonstrating the growth of the intellectual base in research into public opinion. We noted that authors such as Lippmann and Lazarsfeld, who were significant in the field in the periods from 1945-1962 and 1963-1980, were no longer prominent in the following periods. On the other hand, Converse, for example, emerged as an important author in the period from 1963-1980 and remained prominent until the end of the time period covered by the sample. Zaller appears prominently only in the period from 1981-1998, being the most cited author in the co-citation period, at the start of the period spanning 1999-2016. Page, meanwhile, already features in the 
period from 1981-1998, and continues to do so in the following period. As such, in an overall analysis of all the years, Page is the author with the greatest frequency, with Zaller in second place.

Finally, we use another central network to help comprehend the field: document (reference) co-citation network -that appear in the cited references from our sample $(2,536)$.

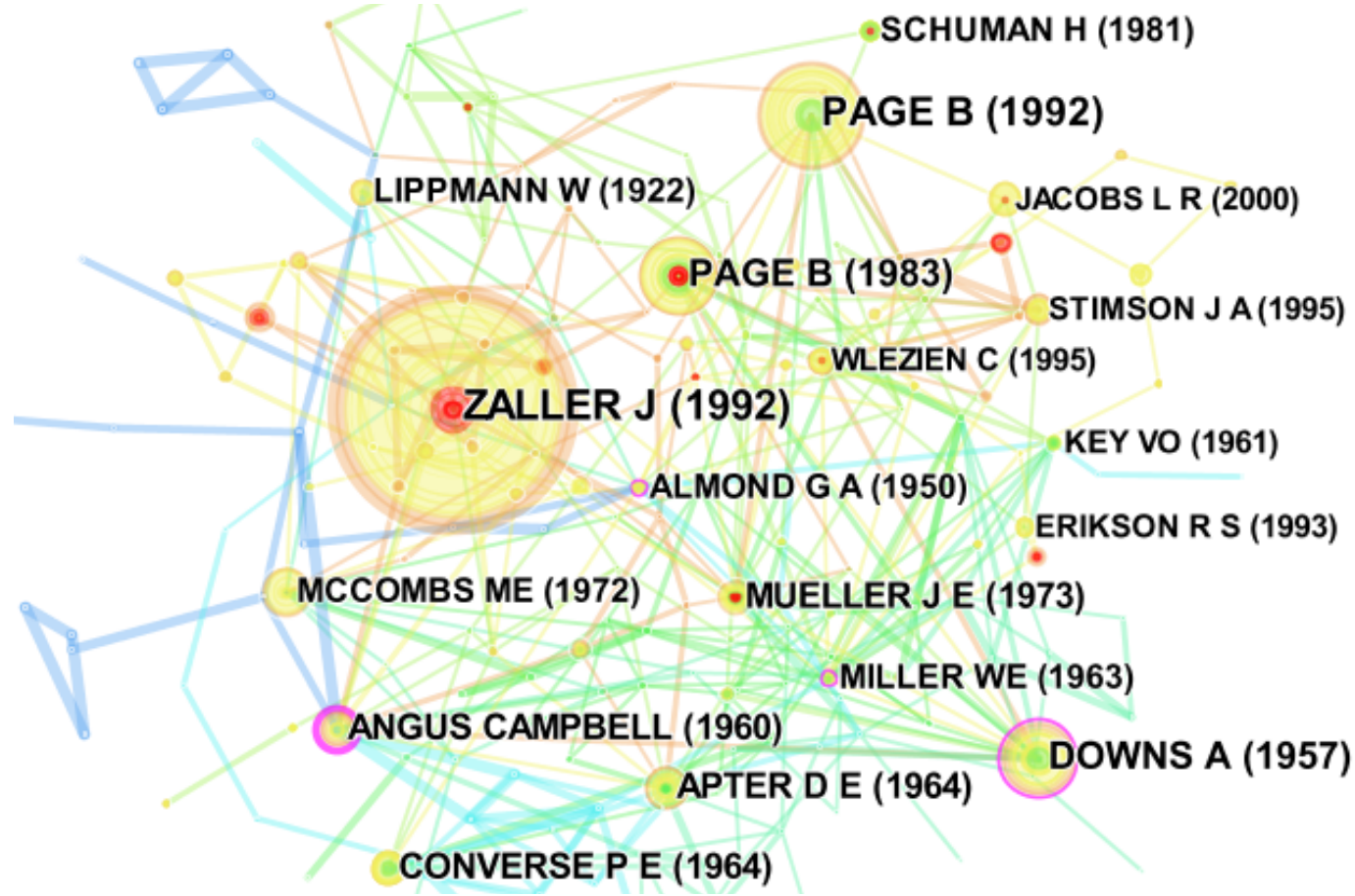

Figure 14 - Document (reference) co-citation network (Year per slice $=10$ ).

Note: only the name of the article's first author appears and the year of publication - full authorship is shown in Table 5.

In Figure 14, we can see that there are various sub-fields of publications on public opinion, carefully demarcated by the predominant literature in each decade: 1950s and 1960s (in blue), 1980s (in green), 1990s (in brown) and 2000s onwards (in yellow).

Through the network from Figure 14, along with Table 5, we can see that the most cited text in the field's intellectual base is the book The Nature and Origins of Mass Opinion, by Zaller (1992). In second place is The Rational Public: Fifty Years of Trends in Americans' Policy Preferences, by Page and Shapiro (1992). The texts by Page and Shapiro (1983), Apter (1964), Campbell (1960) and Converse (1964) are also among the most relevant. Table 5 gives emphasis to the most cited documents in the network, in the book or article format and the total number of citations (Cit.). 
Table 5 - Reference co-citation network summary

\begin{tabular}{|c|c|c|c|}
\hline Title & Reference & Journal/Publisher & Cit. \\
\hline The nature and origins of mass opinion & Zaller - 1992 & Cambridge University press & 158 \\
\hline $\begin{array}{l}\text { The rational public: fifty years of } \\
\text { trends in Americans' policy preferences. }\end{array}$ & $\begin{array}{l}\text { Page and Shapiro - } \\
1992\end{array}$ & Chicago: University of Chicago Press & 93 \\
\hline Effects of public opinion on policy & $\begin{array}{l}\text { Page and Shapiro - } \\
1983\end{array}$ & American Political Science Review & 80 \\
\hline An economic theory of political action in a democracy & Downs - 1957 & The Journal of Political Economy & 73 \\
\hline Ideology and discontent & Apter - 1964 & Collier-Macmillan & 69 \\
\hline Surge and decline: A study of electoral change. & Campbell - 1960 & Public Opinion Quarterly, & 61 \\
\hline The nature of belief systems in mass publics & Converse - 1964 & $\begin{array}{c}\text { In: Ideology and Discontent, ed. David } \\
\text { Apter. New York: Free Press. }\end{array}$ & 61 \\
\hline War, presidents, and public opinion. & Mueller - 1973 & New York: Wiley. & 59 \\
\hline Public opinion & Lippmann - 1922 & New York, NY, US: MacMillan & 54 \\
\hline The agenda-setting function of mass media & $\begin{array}{c}\text { Mccombs and Shaw - } \\
1972\end{array}$ & Public Opinion Quarterly & 53 \\
\hline
\end{tabular}

Zaller (1992) seeks to construct "a theory of the dynamics of public opinion, formalized in a statistical model to study the effects of media on behavior and political attitudes" (Mundim, 2009, p. 2) and this work - The nature and origins of mass opinion - became a reference in debates on political communication, particularly studies on "the media's effects during elections - although it may also be broadly applied in any study of the Effects of the Media".

To complement, we constructed through CitNetExplorer (Van Eck \& Waltman, 2014) a network (Figure 15) that reveals in a timeline that the discussion about public opinion is very old in the academic literature and via data we analyzed it refers especially to 1922 with the publication of Lippman's text called "public opinion".

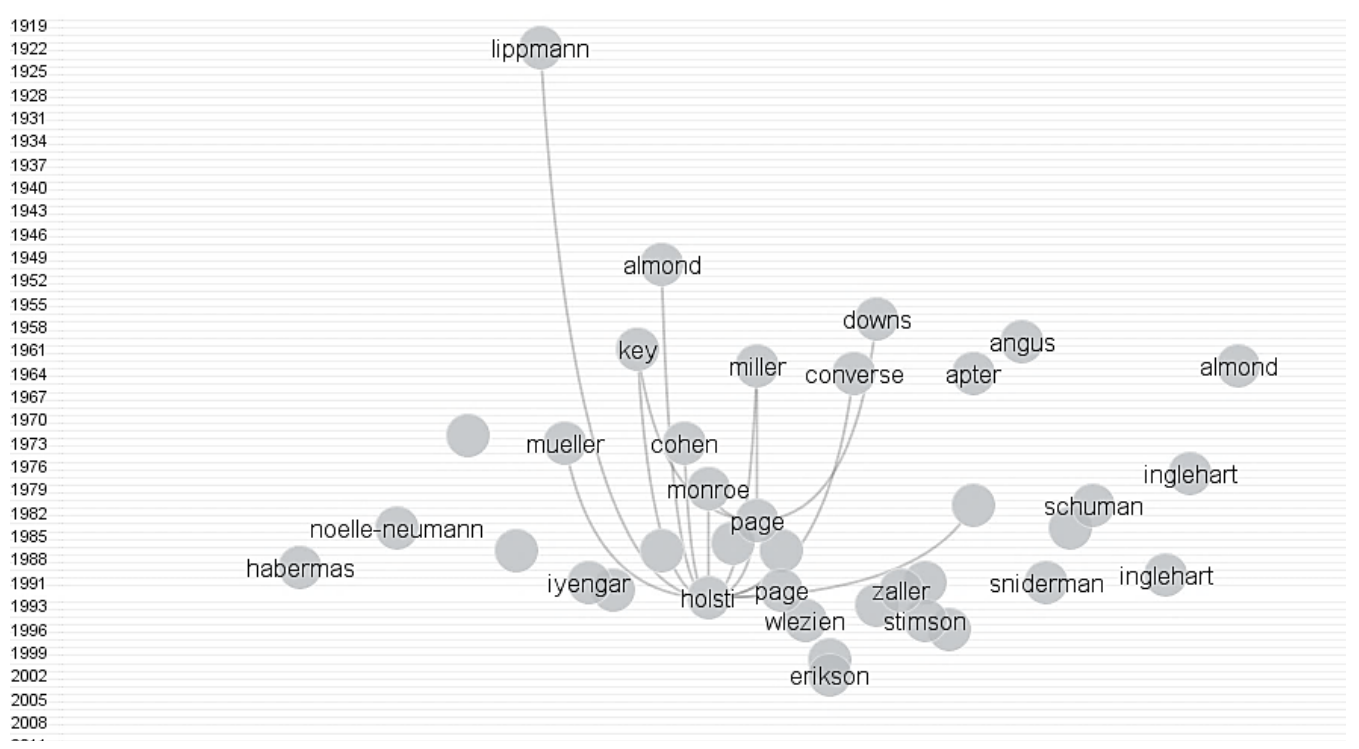

Figure 15 - Citation network in CitNetExplorer. 
Figure 15 also shows that Almond's (1956) text Public-opinion and National-Security Policy is the basis for other authors for the discussion about public opinion, as Downs' (1957) text An economic theory of political action in a democracy. Through this analysis emerged Holsti's (1992) text Public opinion and foreign policy: challenges to the Almond-Lippmann consensus Mershon series: research programs and debates as relevant in the summary of previous debates on public opinion.

Holsti (1992) is an important article for those who intend to discuss public opinion and foreign policy, through the ideas of Almond, Lippmann and other classic authors. Holsti (1992), reflecting on the debates about the role of public opinion in foreign policy, rescues the pessimistic positions of Lippman and Almond, contrasting them with later studies that recognize the importance of public opinion for political decisions.

During the postwar era, Walter Lippmann publications were increasingly skeptical about the ability of public opinion in foreign policy. Their texts have stated that "the common man is too fully engaged in the requirements of earning a living and otherwise attending to his most immediate needs to have the time or inclination to satisfy the heroic, but clearly unrealistic, assumptions about the informed and engaged citizen celebrated in classical democratic theory' (HOLSTI, p. 1992, p. 440). After World War II there was a growth industry in analyses of public opinion. There was too a consensus view that developed during this period: public opinion is "highly volatile and thus it provides very dubious foundations to foreign policy", "public attitudes on foreign affairs are so lacking in structure and coherence", and "public opinion has a very limited impact on the conduct offoreign policy" (Holsti, 1992, p.442).

Others pessimistic conclusions like Lippman publications were emerging. Gabriel Almond in 1973 depicted public opinion as a volatile and mood-driven constraint upon foreign policy. Acoording Holsti (1992, p. 443),

Almond restated his thesis in Lippmannesque language, citing not only the instability of public moods, but other deficiencies as well. He told an audience at the National War College, 'For persons responsible for the making of security policy these mood impacts of the public have a highly irrational effect. Often the public is apathetic when it should be concerned, and panicky when it should be calm'.

Studies of Converse and Cohen also converged on such ideas. Public opinion was identified more as "an entity to be educated rather than a lodestar by which to be guided" (HOLSTI, 1992, p. 444). But this consensus that had emerged during the two decades after World War II was shaken by criticism of the Vietnam War.

Walter Lippmann, who only a little more than a decade earlier had despaired of the tyranny of a feckless public and had called for a stronger executive to counteract the mass public, became a leading critic of the Johnson administration's Vietnam policy; eventually he came to regard the public, which had become increasingly skeptical of the war effort, as more enlightened than the administration. (Holsti, 1992, p. 445).

The initial pessimistic view of Lippman and Almond on the public opinion was challenged by several studies, such as those developed by Caspary and Mueller. However, the most 
comprehensive challenge to the Almond-Lippmann thesis has emerged from studies conducted by Benjamin Page and Robert Shapiro in 1998. "They found that mass opinion in the aggregate is in fact characterized by a good deal of stability, and that this is no less true of foreign policy than on domestic issues". Page and Shapiro stated that when changes appear, they are "reasonable, event driven reactions to the real world" (HOLSTI. 1992, p. 446). We recall that papers from Benjamin Page and Robert Shapiro are prominent in this study as important recent authors in the public opinion field.

However, Holsti (1992, p. 447) warns that "none of these challenges to the AlmondLippmann thesis is based on some newly found evidence that the public is in fact well informed about foreign affairs". In spite of this, new positions of politicians emerge regarding public opinion, as well as new convergences of beliefs based on research. Among these beliefs is "Even though the general public may be rather poorly informed, attitudes about foreign affairs are in fact structured in at least moderately coherent ways" (Holsti, 1992, p. 448).

These studies appear to suggest that, even in the absence of much factual knowledge, members of the mass public use some simple-perhaps even simplistic-heuristics in order to make some sense of an increasingly complex world; a few salient criteria rather than complete information may serve as the bases of judgment. Stated differently, although lacking a deep reservoir of factual information, members of the mass public may operate as "cognitive misers", employing a few superordinate beliefs to guide their thinking on a broad range of issues. For further evidence that people organize their political worlds in richer and more diverse ways than indicated by Converse and his colleagues, see Conover and Feldman (1984). (Holsti, 1992, p. 450).

Anyway, research in recent years has begun to cast doubt on the earlier consensus about public impotence. Page and Shapiro in 1983, for exemple, with a study of public opinion and policy outcomes, showed that $66 \%$ of policy changes analyzed were congruent with changes in public preferences. Although the opinion-policy link is among the largest research gaps in the area, Holsti (1992) argues that there are impressive correlational evidence that policy changes are in fact predominantly in the direction favored by the public. "But our confidence would be enhanced by more substantial evidence of a causal nature", ponders Holsti (1992, p. 459).

We highlight that the position of Lippmann (1922) contrasts, for example, with that of the German philosopher Jürgen Habermas, who also appears in the author co-citation network. Habermas (1996) argues that the legitimacy of political decisions needs to go through the formation of rational public opinion. He claims that this opinion, which is formed through open and equal debate, in the mix of the public arena, is capable of influencing the political system therefore, it is also an idea of popular sovereignty in democracy. The contextualization of these authors' positions shows the range of differing and even opposing positions in the field of studies on public opinion. Finally, the other texts, apart from revealing different concepts of public opinion, also highlight two notable themes from the field - "mass" and politics. 


\section{CONCLUSION}

Public opinion is a controversial concept associated with discussions on manipulation, surveys of opinion, potential for mobilization, influence over public policies, and other topics. Authors with different perspectives and from various areas of knowledge have debated the matter. In the light of this, this paper aimed at systematizing the trends in the field of research on "public opinion". To this end, we carried out a bibliometric analysis of 2,536 articles selected from the Web of Science by Thomson Reuters. Using the CiteSpace software (Chen, 2006), we sought to describe the research front and intellectual base of this research field.

In relation to the research front, we noted the evolution and growth of publications over a period from 1945 to 2016. In our sample, we identified Robert Y. Shapiro (12 articles) and Lawrence R. Jacobs (10 articles) as the most prolific authors. The most referenced articles were those by Gamson and Modigliani (1989), with 1,108 citations, and by Page and Shapiro (1983), with 499 citations. Besides this, the majority of articles were by North American authors (914 articles). The highest number of publications on the theme came from the journals Public Opinion Quarterly (128) and Sotsiologicheskie Issledovaniya (73 articles). The categories with the largest indexation of articles are Government \& Law (844 articles) and Political Science (780 articles). The keywords that appear the most are public opinion (333), attitudes (235), support (126), policy (118), united-states (103) and politics (96).

It is important to consider that it was in the United States that research on public opinion was concentrated at the beginning of the $20^{\text {th }}$ century (Figueiredo \& Cervellini, 1995), and it has maintained this prolonged tradition of studies in the area, given that the majority of the most cited authors and journals are North American. We also confirmed the multidisciplinary nature of interest in the concept, with a variety of authors, journals, categories, and keywords that indicate studies in different areas of knowledge.

In relation to the intellectual base, in the journal co-citation network the journals Public Opinion Quarterly (674), American Political Science Review (611) and American Journal of Political Science (501) stood out. The author co-citation network showed Page and Zaller as the most prominent authors, while it is important to note that there were significant changes in the central authors from the field over the period from 1945 to 2016. Finally, in the analysis of the references co-citation, the most frequently occurring texts in the network were Zaller (1992) (158) and Page and Shapiro (1992). Based on the intellectual base, we observed that a large number of journals, authors and articles can be a factor that contributes to difficulties in formulating a single, allencompassing concept for the term public opinion, since, as discussed, the concept is multidisciplinary (Figueiredo \& Cervellini, 1995).

Results show that scientific output on public opinion is on the increase and that the theme is plural (multidisciplinary) in its approaches, research areas and study subjects. The concept was defined at the end of the 19th century and beginning of the $20^{\text {th }}$ century, when the expression started to be used with its contemporary connotation (Borges, 2014), before developing and adapting to historical social, economic and transnational contexts, while also being the subject of debate, challenges, redimensioning and reverence for diverse research. It is also noted, as per Figueiredo and Cevellini (1995), that the most appropriate term would be "public opinions", given that there is no sole understanding that may be singularized for this expression. Finally, based on this bibliometric analysis, new theoretical and empirical research 
may be performed bearing in mind the continuous and dynamic expansion of the research front and the intellectual base.

\section{REFERENCES}

Almond, G. A. (1956). Public-opinion and national-security policy. Public Opinion Quarterly, 20(2), 371-378, doi:10.1086/266634.

American Political Science Review (APSR). (2016, 22 de April). About the Journal. Retrieved from www.cambridge.org/core/journals/american-political-science-review.

Apter, D. E. (Ed.). (1964). Ideology and discontent (Vol. 5). Free Pr.

Morettin, P. A., \& Toloi, C. (2006). Análise de séries temporais (2a ed.). São Paulo: Edgard Blucher.

Borges, S. (2014). Opinião Pública: história, crítica e desafios na era transnacional. Exedra, 9, 85103.

Bornmann, L., \& Mutz, R. (2015). Growth rates of modern science: A bibliometric analysis based on the number of publications and cited references. Journal of the Association for Information Science and Technology, 66(11), 2215-2222.

Bourdieu, P. (1980). A public opinion não existe. Questões de sociologia.

Bourdieu, P. (1994). O campo científico. In R. Ortiz, (Org.), Pierre Bourdieu: sociologia (pp. 122155). São Paulo, Ed. Ática.

Burstein, P. (2003). The impact of public opinion on public policy: A review and an agenda. Political Research Quarterly, 56(1), 29-40, doi:10.1177/106591290305600103.

Calver, H. N., \& Wingo, O. T. (1947). Public Opinion Measurement as an Instrument in Public Health Practice. Am J Public Health Nations Health, 37(4), 426-430.

Campbell, A. (1960). Surge and decline: A study of electoral change. Public Opinion Quarterly, 24(3), 397-418, doi:10.1086/266960.

Chen, C. (2004). Searching for intellectual turning points: Progressive knowledge domain visualization. Proceedings of the National Academy of Sciences, 101(1), 5303-5310.

Chen, C. (2006). CiteSpace II: Detecting and visualizing emerging trends and transient patterns in scientific literature. JASIST, 57(3), 359-377, doi:10.1002/asi.20317.

Chen, C. (2012). Knowledge domain analysis. In Turning points: The nature of creativity, 139-75. Berlin, Heidelberg: Springer. doi:10.1007/978-3-642-19160-2

Chen, C., Ibekwe-SanJuan, F., \& Hou, J. (2010). The structure and dynamics of co-citation clusters: A multiple-perspective co-citation analysis. Journal of the American Society for Information Science and Technology, 61(7), 1386-1409. doi:10.1002/asi.21309

Converse, P. E. (1964). The Nature of Belief Systems in Mass Publics. In D. E. Apter (Ed.), Ideology and Discontent, New York: Free Press.

Costa, D. F., Carvalho, F. M.; Moreira, B. C. M., \& Prado, J. W. (2017). Bibliometric analysis on the association between behavioral finance and decision making with cognitive biases such as 
overconfidence, anchoring effect and confirmation bias. Scientometrics, 111(3), 17751799, doi:10.1007/s11192-017-2371-5.

Dunning, T. (1993). Accurate Methods for the Statistics of Surprise and Coincidence. Computational Linguistics, 19, 61-74. Retrieved from http://portal.acm.org/citation.cfm?id=972454

Feldman, S. (1988). Structure and consistency in public-opinion - the role of core beliefs and values. American Journal of Political Science, 32(2), 416-440, doi:10.2307/2111130.

Figueiredo, R., \& Cervellini, S. (1995). Contribuição para o Conceito de public opinion. Opinião pública, 3(3), 171-185.

Gamson, W. A., \& Modigliani, A. (1989). Media discourse and public-opinion on nuclear-power - a constructionist approach. American Journal of Sociology, 95(1), 1-37.

Guimarães, J., \& Amorim, A. P. (2013). A corrupção da public opinion. Uma defesa republicana da liberdade de expressão. São Paulo: Boitempo.

Habermas, J. (1996). Between facts and norms: contributions to a discourse theory of law and democracy. Cambridge, Massachusetts: The MIT Press.

Habermas, J. (2003). Mudança estrutural da esfera public: investigações quanto a uma categoria da sociedade burguesa. Rio de Janeiro: Tempo Brasileiro.

Hagstrom, W. O. (1965). The scientific community. New York: Basic Books.

Herek, G. M. (2002). Gender gaps in public opinion about lesbians and gay men. Public Opinion Quarterly, 66(1), 40-66, doi:10.1086/338409.

Hyman, H. (1945). Community background in public opinion research. Journal of Abnormal and Social Psychology, 40(4), 411-413, doi:10.1037/h0059978.

Holsti, O. R. (1992). Public opinion and foreign policy: Challenges to the Almond-Lippmann consensus. International Studies Quarterly, 36(4), 439-466, doi: 10.2307/2600734.

Jacobs, L. R., \& Mettler, S. (2011). Why Public Opinion Changes: The Implications for Health and Health Policy. Journal of Health Politics Policy and Law, 36(6), 917-933.

Jacobs, L. R., \& Shapiro, R. Y. (1989). Public-opinion and the new social-history - some lessons for the study of public-opinion and democratic policy-making. Social Science History, 13(1), 124, doi:10.2307/1171211.

Lippmann, W. (1922). Public opinion, (pp. 3-32). New York, NY: MacMillan Co.

Mann, H. B. (1945). On a problem of estimation occurring in public opinion polls. Annals of Mathematical Statistics, 16(1), 85-90, doi:10.1214/aoms/1177731174.

Mateus, S. (2008). A Estrela (De)Cadente: para uma breve história da public opinion. Estudos de Comunicação, 4, 59-80.

Mueller, J. E. (1973). War, presidents, and public opinion. New York: Wiley.

Mundim, P. S. (2010). A teoria da dinâmica da opinião pública de John R. Zaller: Aplicações para o caso brasileiro. Contemporânea - Revista de Comunicação e Cultura, 7(2), 1-29.

Newport, F., Shapiro, R. Y., Ayres, W., Belden, N., Fishkin, J., Fung, A., et al. (2013). Polling and democracy executive summary of the aapor task force report on public opinion and leadership. Public Opinion Quarterly, 77(4), 853-860. 
Noelle-Neumann (1974). Spiral of silence - theory of public opinion. Journal of Communication, 24(2), 43-51, doi:10.1111/j.1460-2466.1974.tb00367.x.

Nowak, A., Szamrej, J., \& Latané, B. (1990). From private attitude to public opinion: A dynamic theory of social impact. Psychological Review, 97(3), 362-376.

Page, B. I., \& Shapiro, R. Y. (1983). Effects of public opinion on policy. American political science review, 77(1), 175-190.

Page, B. I., \& Shapiro, R. Y. (1992). The Rational Public: Fifty Years of Trends in Americans' Policy Preferences. University of Chicago Press.

Page, B. I., Shapiro, R. Y., \& Dempsey, G. R. (1987). What moves public-opinion. American Political Science Review, 81(1), 23-43, doi:10.2307/1960777.

Perrin, A. J., \& Mcfarland, K. (2011). Social Theory and Public Opinion. Annual Review of Sociology, 37, 87-107.

Pinto, C. F., Serra, F. R., \& Ferreira, M. P. (2014). A bibliometric study on culture research in international business. BAR, Braz. Adm. Rev, 11(3), 340-363.

Prado, J. W., Alcântara, V. C., Carvalho, F. M., Vieira, K. C., Machado, L. K. C., \& Tonelli, D. F. (2016). Multivariate analysis of credit risk and bankruptcy research data: a bibliometric study involving different knowledge fields (1968-2014). Scientometrics, 106(3), 10071029, doi:10.1007/s11192-015-1829-6.

Price, V. (2008). The public and public opinion in political theories. In W. Donsbach, \& M. W. Traugott (Ed.), Handbook of Public Opinion Reserch (pp. 11-24). Sage Publication.

Public Opinion Quarterly. (2016, 22 de April). About the Journal. Retrieved from https://poq.oxfordjournals.org/.

Shapiro, R. Y. (2011). Public Opinion and American Democracy. Public Opinion Quarterly, 75(5), 982-1017, doi:10.1093/poq/nfr053.

Van Eck, N. J., \& Waltman, L. (2010). Software survey: VOSviewer, a computer program for bibliometric mapping. Scientometrics, 84(2), 523-538.

Van Eck, N. J., \& Waltman, L. (2014). CitNetExplorer: A new software tool for analyzing and visualizing citation networks. Journal of Informetrics, 8(4), 802-823.

Zaller, J. (1992). The nature and origins of mass opinion. Cambridge university press. 